\title{
Spatio-seasonal variability of chromophoric dissolved organic matter absorption and responses to photobleaching in a large shallow temperate lake
}

\author{
María Encina Aulló-Maestro ${ }^{1}$, Peter Hunter ${ }^{1}$, Evangelos Spyrakos ${ }^{1}$, Pierre Mercatoris ${ }^{1,2}$, Attila Kovács ${ }^{3}$, \\ Hajnalka Horváth $^{3}$, Tom Preston ${ }^{4}$, Mátyás Présing ${ }^{3}$, Jesús Torres Palenzuela ${ }^{5}$, and Andrew Tyler ${ }^{1}$ \\ ${ }^{1}$ Biological and Environmental Science, School of Natural Sciences, University of Stirling, Stirling, UK \\ ${ }^{2}$ Plymouth Marine Laboratory, Plymouth, UK \\ ${ }^{3}$ Balaton Limnological Institute, MTA Centre for Ecological Research, Tihany, Hungary \\ ${ }^{4}$ Stable Isotope Biochemistry Laboratory, SUERC, East Kilbride, UK \\ ${ }^{5}$ Remote Sensing and GIS Laboratory, Department of Applied Physics, Sciences Faculty, University of Vigo, Vigo, Spain
}

Correspondence to: María Encina Aulló-Maestro (meaullo@gmail.com)

Received: 8 August 2016 - Discussion started: 12 August 2016

Revised: 10 December 2016 - Accepted: 25 January 2017 - Published: 14 March 2017

\begin{abstract}
The development and validation of remotesensing-based approaches for the retrieval of chromophoric dissolved organic matter (CDOM) concentrations requires a comprehensive understanding of the sources and magnitude of variability in the optical properties of dissolved material within lakes. In this study, spatial and seasonal variability in concentration and composition of CDOM and the origin of its variation was studied in Lake Balaton (Hungary), a large temperate shallow lake in central Europe. In addition, we investigated the effect of photobleaching on the optical properties of CDOM through in-lake incubation experiments. There was marked variability throughout the year in CDOM absorption in Lake Balaton $\left(a_{\mathrm{CDOM}}(440)=0.06-\right.$ $\left.9.01 \mathrm{~m}^{-1}\right)$. The highest values were consistently observed at the mouth of the main inflow (Zala River), which drains humic-rich material from the adjoining Kis-Balaton wetland, but CDOM absorption decreased rapidly towards the east where it was consistently lower and less variable than in the westernmost lake basins. The spectral slope parameter for the interval of $350-500 \mathrm{~nm}\left(S_{\mathrm{CDOM}}(350-500)\right)$ was more variable with increasing distance from the inflow (observed range $0.0161-0.0181 \mathrm{~nm}^{-1}$ for the mouth of the main inflow and $0.0158-0.0300 \mathrm{~nm}^{-1}$ for waters closer to the outflow). However, spatial variation in $S_{\mathrm{CDOM}}$ was more constant exhibiting a negative correlation with $a_{\mathrm{CDOM}}(440)$. Dissolved organic carbon (DOC) was strongly positively corre-
\end{abstract}

lated with $a_{\mathrm{CDOM}}(440)$ and followed a similar seasonal trend but it demonstrated more variability than either $a_{\mathrm{CDOM}}$ or

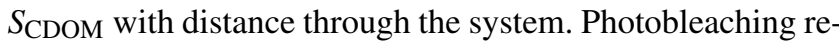
sulting from a 7-day exposure to natural solar UV radiation resulted in a marked decrease in allochthonous CDOM absorption ( 7.04 to $3.36 \mathrm{~m}^{-1}, 42 \%$ decrease). Photodegradation also resulted in an increase in the spectral slope coefficient of dissolved material.

\section{Introduction}

\subsection{Importance of CDOM in lakes}

There are approximately 117 million lakes on Earth greater than $0.002 \mathrm{~km}^{2}$ in surface area collectively covering about $3.7 \%$ of its non-glacial surface (Verpoorter et al., 2014). The importance of the role that lakes play as regulators of the carbon cycle and thereby global climate has only recently been recognised (Tranvik et al., 2009). They act as both a sink (sediment storage through flocculation from dissolved to particulate organic carbon) and a source for carbon (degradation and resulting mineralisation to $\mathrm{CH}_{4}, \mathrm{CO}$ and $\mathrm{CO}_{2}$; Cole et al., 2007; Benoy et al., 2007; Tranvik et al., 2009). As a result they also play an important role in transforming and releasing terrestrially derived carbon to the atmosphere and ocean (Tranvik et al., 2009). As extremely sensi- 
tive ecosystems (Millennium Ecosystem Assessment, 2005; IPCC, 2007), lakes can respond rapidly to external pressures including meteorology, climate and land use change. This has led to the emerging concept of lakes as sentinels of environmental change (Adrian et al., 2009; Williamson et al., 2009a, b; Schindler, 2009).

The optical properties of lakes provide particularly useful metrics for measuring ecosystem change (Vincent et al., 1998) as they not only convey information on the quantity of particulate and dissolved material but also its quality (Williamson et al., 2014). Furthermore, understanding how the optical properties of particulate and dissolved material in lakes influence the underwater light field and water-leaving radiative signal is important for the development and application of remote sensing techniques for lake monitoring and assessment, but also for their application to lake carbon studies.

Much of the dissolved organic matter (DOM) found in lakes typically represents between 90 and $100 \%$ of the total carbon pool (Wilkinson et al., 2013) and is derived from terrestrial inputs, transported through streams, rivers and wetlands. This allochthonous component of the DOM originates from soils, sediments and plants and is primarily composed of humic substances. The autochthonous fraction of DOM is produced mostly by phytoplankton, zooplankton and bacterioplankton and is largely composed of fulvic acids, carbohydrates, amino acids, proteins, lipids and organic acids.

Chromophoric dissolved organic matter (CDOM) is the coloured fraction of DOM. It is one of the dominant colourforming constituents in lakes: it not only exerts a strong influence over the underwater light field and water-leaving radiance but it also has a number of important ecosystem functions. First of all, it absorbs light strongly in the ultraviolet (UV) spectrum, limiting the penetration of biologically damaging UV-B radiation that provides protection for phytoplankton and other primary producers (Hoge et al., 1995; Laurion et al., 2000; Zhang et al., 2007a; Williamson et al., 2001). In addition, CDOM can be remineralised by bacteria acting as a source of inorganic nutrients (Buchan et al., 2014), which is important for phytoplankton nutrition, thus fulfilling an important role in the development of phytoplankton blooms and lake metabolism more widely. On the other hand, studies have also shown that light absorption by CDOM can reduce the amount and quality of photosynthetically active radiation (PAR) available to phytoplankton, thereby decreasing primary production and constraining lake metabolism (Kirk, 1994; Laurion et al., 1997, 2000; Vähätalo et al., 2005). Moreover, its conservative properties with dissolved organic carbon (DOC), means CDOM is often used as a proxy for DOC. Thus, there is substantial interest in the use of CDOM as an optical tracer of DOC due to the importance of the latter in regulating physical, chemical and biological properties of lakes. It is therefore important that we develop a better understanding of the optical properties of CDOM and how these relate to the chemical composition and concentra- tion of DOM whether driven by changes to source relationships or through the in-lake processes and transformation of the carbon pool.

Understanding how the optical properties of CDOM vary both temporally and spatially within lakes and how the observed variability influences the underwater light field is of particular importance for the development and validation of remote-sensing-based approaches for retrieving CDOM concentrations. The recent launch of new satellite missions (e.g. Sentinel-2 and -3), allied with the prospect of new hyperspectral sensors (e.g. EnMAP), has provided a new impetus for the development and application of remote sensing techniques for the assessment and monitoring of inland water quality. However, CDOM is arguably the most challenging water quality parameter for the reliable estimation of remotely sensed observations (Palmer et al., 2015) and, in spite of its importance to the physical, chemical and biological function of lakes, it remains one of the least studied parameters. Indeed, few studies have explored the application of remote sensing for the estimation of CDOM in lakes. To progress with such research, an improved understanding of the spatial and temporal variation in the optical properties of CDOM in lakes is needed.

\subsection{Optical properties of CDOM}

CDOM concentration is commonly measured by its absorption coefficient $\left(a_{\mathrm{CDOM}}\right)$ at $440 \mathrm{~nm}$, whereas its structure and composition has been most commonly inferred from the spectral slope parameter $\left(S_{\mathrm{CDOM}}\right)$ calculated between two reference wavelengths (Helms et al., 2008; Fichot and Benner, 2012). Other optical metrics related to CDOM compositions include the $E 2: E 3$ ratio or $M$ value, which is the ratio of absorption at 250 and $365 \mathrm{~nm}$. De Haan and De Boer (1987) used the $E 2: E 3$ ratio to track changes in relative size of CDOM molecules: increases in molecular size result in decreases in the $E 2: E 3$ ratio because of stronger light absorption by higher molecular weight compounds at longer wavelengths.

In addition, Weishaar et al. (2003) introduced the specific UV absorbance parameter $\left(\mathrm{SUVA}_{254}\right)$ defined as the UV absorbance at $254 \mathrm{~nm}$ normalised by the DOC concentration. SUVA 254 has been shown to be strongly correlated with DOM aromaticity in a large number of aquatic environments, with higher $\mathrm{SUVA}_{254}$ values indicative of a higher abundance of aromatic compounds. Previous studies have used $\mathrm{SUVA}_{254}$ to explore variability in the composition of DOM in natural waters.

The compositional properties of CDOM vary over time in response to processes such as microbial decomposition and exposure to UV irradiation. Previous studies have shown the latter process, first described by Wipple (1914) as "photobleaching", plays a major role in the transformation of DOM in natural waters. Exposure to solar irradiance has been shown to reduce its capacity to absorb light; the loss of ab- 
sorptivity is linked to a reduction in molecular weight (MW), alteration of its chemical composition and an increase in the bioavailability of DOM (Geller, 1986; Keiber et al., 1990; Wetzel et al., 1995; Lindell et al., 1995; Corin et al., 1996; Reche et al., 1998) with implications for lake metabolism. $S_{\mathrm{CDOM}}$ is also known to vary in response to photobleaching (Swan et al., 2012; Fichot and Benner, 2012).

Most previous studies on the origin, distribution and degradation of DOM and how it influences the optical properties of CDOM have been undertaken in oceans (Andrew et al., 2013; Matsuoka et al., 2014; Hancke et al., 2014; D'Sa et al., 2014), coastal waters (Stedmon et al., 2000; Vantrepotte et al., 2007; Kutser et al., 2009; Para et al., 2013) or in highlatitude lakes (Ficek et al., 2011; Ylöstalo et al., 2014). Understandably, the bias towards high-latitude systems partly reflects the fact that this region contains a high density of humic-rich lakes. There is a relatively rich literature on DOM in temperate lakes (e.g. Zhang et al., 2011; Read and Rose, 2013; Müller et al., 2014) but few studies have focused on large shallow lakes like Lake Balaton with a continental climate; hence our understanding of the variability in CDOM optical properties in these systems is comparatively poorer. In systems such as Lake Balaton, although the DOC pool is typically smaller than at higher latitudes it still plays a significant role in regulating light availability and therefore lake metabolism, while the influence of processes such as photobleaching is also likely to be more pronounced.

In this study we explore spatial and seasonal variability in optical properties of CDOM in Lake Balaton, a large temperate lake with a highly continental climate. We investigate how changes in spectral absorption, spectral slope coefficients, $\mathrm{SUVA}_{254}$ and the $E 2: E 3$ raFtio can be used to infer information on the concentration, source and decomposition of CDOM. The main objectives of the study were to (1) characterise the spatial and seasonal trends in CDOM in Lake Balaton over the course of a year and to (2) determine the origin and magnitude of the variability of different sources of CDOM.

\section{Material and methods}

\subsection{Study site}

With a surface area of $596 \mathrm{~km}^{2}$ and a mean depth of $3.25 \mathrm{~m}$, Lake Balaton in Hungary is the largest shallow lake in central Europe (Fig. 1a). The region is situated on the boundaries between the Mediterranean, continental, and oceanic climatic zones (Peel et al., 2006), resulting in a climate characterised by dry summers and moderately wet winters with typical continental extremes in temperature. The first two weeks of January are the coldest periods of the year $\left(-4-3^{\circ} \mathrm{C}\right)$ whilst July and August the warmest months $\left(15-28^{\circ} \mathrm{C}\right)$. The annual precipitation in the Lake Balaton region is between 500 and $750 \mathrm{~mm}$; most precipitation falls during the spring, while the minimum occurs during the summer. There is a secondary maximum in autumn, due to a strong cyclone activity at that time of the year. With regard to solar radiation, Lake Balaton is situated between the southern, western and central Transdanubian regions in Hungary with an annual mean of $4500 \mathrm{MJ} \mathrm{m}^{-2}$. The highest solar radiation is received in July $\left(650 \mathrm{MJ} \mathrm{m}^{-2}\right)$, while cloudy weather and shorter days mean that lowest radiation occurs in December. The maximum in sunshine duration is also reached in July with more than $250 \mathrm{~h}$, falling to a minimum of approximately $40 \mathrm{~h}$ during winter months.

Lake Balaton is usually divided into four basins (southwest to north-east): Keszthely, Szigliget, Szemes and Siófok (Fig. 1b). The lake has 20 permanent and 31 temporary inflows, many of which are small streams or springs in the lake bed. The largest inflow to the lake is the Zala River, which flows through Kis-Balaton reservoir - a large semi-natural wetland system - and enters the lake in the westernmost part of Keszthely basin (Fig. 1b). The only outflow is the Sió channel in the north-east that connects the Siófok basin with the Danube River.

Lake Balaton has experienced eutrophication since the middle of the 18th century due to agricultural intensification and urbanisation within the catchment. Since the early 1980s, significant effort has been invested in improving its water quality (Tátrai et al., 2000). The construction of Kis-Balaton reservoir and wetland system was one of the main engineering controls built to reduce nutrient inflow from the Zala River and the overall loading within the lake. Kis-Balaton removes approximately $60 \%$ of the annual nutrient loading to Lake Balaton (Szilágyi et al., 1990). However, nutrient inputs from the Zala River still result in high summer primary production in the eutrophic $\left(>20 \mathrm{mg} \mathrm{m}^{-3} \mathrm{chl} a\right)$ waters in the western basins, with a steep gradient towards more mesotrophic (2-20 $\mathrm{mg} \mathrm{m}^{-3} \mathrm{chl} a$ ) waters in the east. The hypertrophic Kis-Balaton wetland system is believed to be responsible for much of the DOM entering the lake, largely derived from luxuriant growth and decomposition of aquatic plants. Previous research (Palmer et al., 2013; Riddick et al., 2015) has shown that CDOM is usually significantly higher close to the Zala River inflow, and decreases towards the outflow but very little is known about the seasonal dynamics of CDOM in the system.

Suspended particulate matter in Lake Balaton is highly variable (spatially and temporally) due to its very shallow depth, constant mixing and susceptibility to wind-driven resuspension events (Istvánovics et al., 2004). Phytoplankton composition in the lake shows strong seasonal trends, with two annual blooms (Padisak and Reynolds, 1998; Présing et al., 2008; Hajnal and Padisák, 2008). In late summer and early autumn, cyanobacterial blooms often occur in the Keszthely basin (I), extending westwards to the Szigliget (II) and Szemes (III) basins and very occasionally to the Siófok (IV) basin (Padisak and Reynolds, 1998; Présing et al., 2008; Hajnal and Padisák, 2008). The lowest phytoplankton 


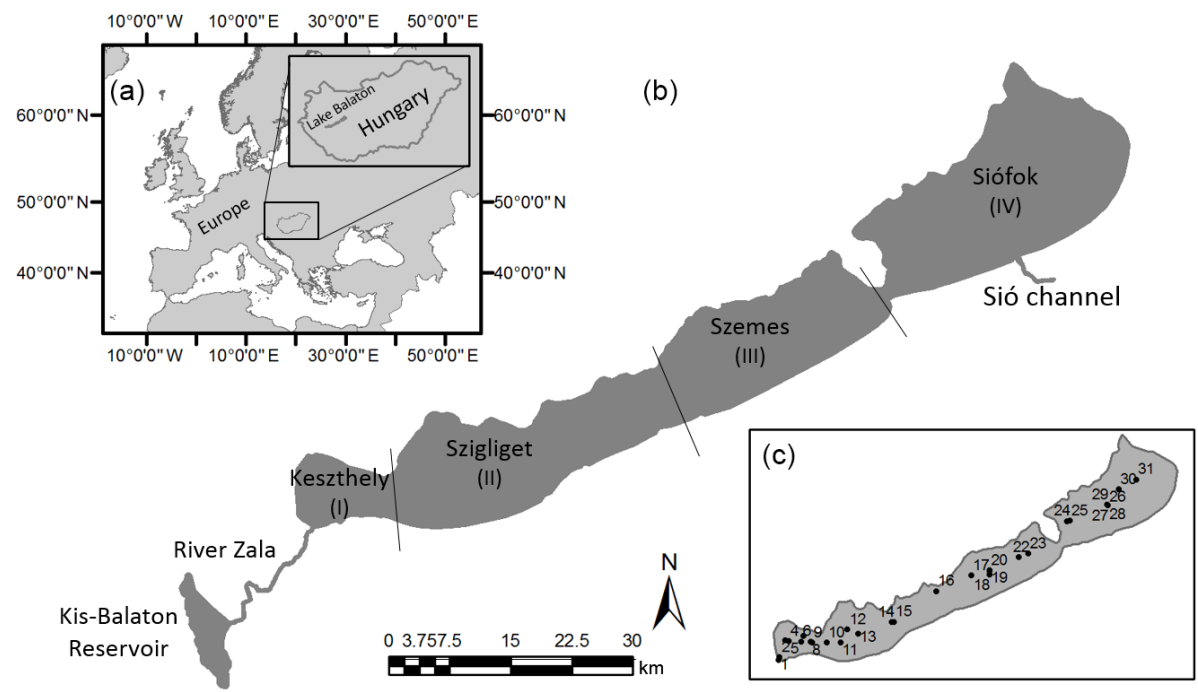

Figure 1. (a) Location of Lake Balaton within Europe. (b) Map of basins, Kis-Balaton reservoir, Zala River and Sió channel. (c) Location of 31 sampling stations in Lake Balaton.

biomass generally occurs in February when the lake can be ice covered; a small dinoflagellate bloom may also occur in April (Mózes et al., 2006).

\subsection{Water sampling}

Spatial variability in CDOM quantity and quality was assessed over a 1-week period in July 2013 (6 stations) and a 3-week period in July 2014 (25 stations) at 31 stations over a biogeochemical gradient from the south-west in the water masses influenced by Zala River to the north-east near the outflow (Fig. 1c). Five stations were also sampled in the Kis-Balaton reservoir during the same period ( 2 in 2013 and 3 2014). These intensive sampling campaigns were timed to coincide with the annual summer peak in DOC to capture the maximum spatial variability likely to occur in the system.

In order to capture seasonal variability in CDOM quantity and quality, water samples were collected fortnightly at 6 long-term monitoring stations on Lake Balaton over the course of 7 months (March to September 2014). These comprised stations 01 and 03 from Keszthely basin (I), station 12 from Szigliget basin (II), station 20 from Szemes basin (III) and stations 25 and 30 from Siófok basin (IV) (for location of stations see Fig. 1c).

Water samples for DOC analysis were collected in triplicate using acid-rinsed polypropylene bottles at $0.3 \mathrm{~m}$ depth below the surface. The samples were immediately stored on ice and in the dark until they were transferred to the laboratory for filtration. The samples were filtered through $0.7 \mu \mathrm{m}$ precombusted $47 \mathrm{~mm}$ glass-fibre membranes (Whatman $\mathrm{GF} / \mathrm{F})$ and stored cold $\left(4^{\circ} \mathrm{C}\right)$ and in the dark until measurement. Filters were selected for DOC measurements because of their compatibility with other particulate organic carbon (POC) measurements and were combusted, reducing the possibility of contamination. Even though, due to their large nominal pore size, these filters are expected to allow a high number of bacteria, viruses and colloids through, the differences with a smaller nominal pore size are expected to be small given that this DOC was only used to correlate with $a_{\mathrm{CDOM}}$. Samples for CDOM analysis were collected separately in acid-rinsed amber glass bottles from $0.3 \mathrm{~m}$ depth and immediately stored on ice and in the dark until transfer to the laboratory. Samples were prefiltered through precombusted $0.7 \mu \mathrm{m}$ pore size glass-fibre membranes (Whatman $\mathrm{GF} / \mathrm{F}$ ) to remove large particles and then refiltered through a $0.2 \mu \mathrm{m}$ Whatman nucleopore membrane filters. The samples collected as part of the seasonal sampling campaign were measured fresh (i.e. without preservation) within $24 \mathrm{~h}$ following Tilstone et al. (2002). The samples collected during the campaigns focused on spatial variability were preserved with a $0.5 \%$ ( $\mathrm{vol}$ : vol) solution of $10 \mathrm{~g} \mathrm{~L}^{-1}$ of sodium azide $\left(\mathrm{NaN}_{3}\right)$ (Ferrari et al., 1996) prior to analysis, which was completed within 1 month of sample collection.

\subsection{CDOM absorption}

The spectral absorbance $(A)$ of the seasonal samples was measured on a Shimadzu UV 1601 spectrophotometer (Cuthbert and Del Giorgio, 1992) using a 1, 4 or $10 \mathrm{~cm}$ cuvette between 350 and $800 \mathrm{~nm}$ with a $0.5 \mathrm{~nm}$ sampling interval using ultrapure water (Milli-Q) as a reference (Vodacek et al., 1997). These samples were measured fresh in the laboratory of the Balaton Limnological Institute. Samples from campaigns focused on spatial variability were preserved immediately with $0.5 \%$ (vol: vol) sodium azide and transported to the University of Stirling for analysis on a Cary-100 UVvisible spectrophotometer. A 1 or $10 \mathrm{~cm}$ cuvette was used between 200 and $800 \mathrm{~nm}$ with $0.2 \mathrm{~nm}$ sampling interval against 
ultrapure water with $0.5 \%$ (vol: vol) sodium azide as the reference. The absorbance data were baseline corrected by subtracting the mean of $a_{\mathrm{CDOM}}$ in a $5 \mathrm{~nm}$ interval centred at $685 \mathrm{~nm}$ (after Babin et al., 2003). This wavelength was selected because absorption by CDOM and other dissolved constituents is negligible in the far red (Pegau et al., 1997). The CDOM spectral absorption coefficient $\left(a_{\mathrm{CDOM}}\right)$ was calculated as follows (Kirk, 2010):

$a_{\mathrm{CDOM}}\left(\lambda, \mathrm{m}^{-1}\right)=2.303 \cdot \frac{A_{\mathrm{CDOM}}(\lambda)}{L}$,

where $a_{\mathrm{CDOM}}(\lambda)$ is the absorbance over a pathlength of $L$ metres.

The absorption coefficient at $440 \mathrm{~nm}$ was used to express variation in CDOM quantity. This wavelength was preferred over UV wavelengths because it is more relevant to (and consistent with previous) studies on the optical properties and remote sensing of CDOM in natural waters (e.g. Carder et al., 1989; Nelson et al., 1998; Schwarz et al., 2002). The spectral slope for the interval of 350-500 nm $\left(S_{\mathrm{CDOM}}(350-500)\right)$ (Babin et al., 2003) was determined by fitting a single decreasing exponential function to the absorption spectra using non-linear regression (Bricaud et al., 1981; Twardowski et al., 2004) between 350 and $500 \mathrm{~nm}$, as follows:

$a_{\lambda}(\mathrm{nm})=a_{\lambda_{\mathrm{ref}}} \cdot e^{-S\left(\lambda-\lambda_{\mathrm{ref}}\right)}$,

where $\lambda_{\text {ref }}$ is a reference wavelength ( $440 \mathrm{~nm}$ in this study). This range of calculation was consistent with Babin et al. (2003) and Matsuoka et al. (2012) among others and is more relevant to remote sensing studies than the use of wavelength ranges that extend into the UV spectrum.

The $E 2 / E 3$ index was calculated as the ratio of the CDOM absorption coefficients at 250 and $365 \mathrm{~nm}$. Previous studies have shown that decreases in this ratio are related to increases in molecular size, aromaticity and humification of DOC (Peuravuori and Pihlaja, 1997). Finally, specific UV absorptivity at $254 \mathrm{~nm}\left(\mathrm{SUVA}_{254}\right)$ was obtained by normalising the absorption at $254 \mathrm{~nm}$ by the DOC concentration $\left(\mathrm{mg} \mathrm{L}^{-1}\right)$ (Weishaar et al., 2003).

\subsection{Dissolved organic carbon (DOC)}

Samples for dissolved organic carbon (DOC) were measured by thermal catalysis at $950^{\circ} \mathrm{C}$ in an Elementar High TOC instrument (Elementar Analysensysteme GmbH Germany) equipped with a platinum catalyst cartridge using synthetic air as the carrier gas. For spatial measurements, DOC data were only available for 18 out of 31 stations (Table 3 ).

\subsection{CDOM photodegradation}

In order to examine the effects of solar radiation on autochthonous and allochthonous CDOM in Lake Balaton, a 7-day in-lake incubation experiment was undertaken during
mid-July 2014. CDOM samples from Lake Balaton were incubated in $65 \mathrm{~mL}$ capacity quartz tubes over 7 days under natural solar radiation. The mean daytime lake temperature of the lake over the experimental period was $24.6^{\circ} \mathrm{C}$. The quartz tubes were attached horizontally to a wire frame to minimise shading and submerged approximately $1 \mathrm{~cm}$ beneath the water surface in a sheltered bay. In total, 56 samples were taken of which 21 experimental samples were composed of phytoplankton-derived autochthonous CDOM $\left(\mathrm{CDOM}_{\text {auto }}\right)$ and a further 21 were comprised of CDOM of allochthonous origin $\left(\mathrm{CDOM}_{\text {allo }}\right)$. In addition, 14 dark control samples $\left(\mathrm{CDOM}_{\text {allo-dark }}\right.$ and $\left.\mathrm{CDOM}_{\text {auto-dark }}\right)$ were incubated (7 allochthonous, 7 autochthonous).

The autochthonous CDOM was extracted from a strain of Cylindrospermopsis raciborskii (ACT 9502) previously isolated from Lake Balaton and grown under nutrient replete conditions in semi-continuous culture at $24^{\circ} \mathrm{C}$ and $14: 10 \mathrm{~h}$ light/dark cycle. Cylindrospermopsis raciborskii dominates the phytoplankton community during summer in Lake Balaton (Présing et al., 1996), often contributing $>90 \%$ of the total biomass. A total of $3200 \mathrm{~mL}$ of cultured material was centrifuged in the early stationary growth phase $(5 \mathrm{~min}$, $4000 \mathrm{rpm}$; Hermle Z320 BHG) in order to shake off the remaining allochthonous CDOM in the supernatant and the resulting cell pellet was broken using a mini-bead beater $(30 \mathrm{~s}$, $3500 \mathrm{rpm}$; Biospec products) to facilitate the release of cell contents. The total cell disruption was confirmed by microscopic examination (Olympus BX51). Similar processes take place in natural environments. During some natural process the cell releases its content, for example when grazed by zooplankton, (Levine et al., 1999) or in the presence of algal viruses causing the lysis of natural phytoplankton communities (Suttle et al., 1990). The material was incubated in the dark for 5 days at $20^{\circ} \mathrm{C}$ to allow production of CDOM and then diluted to $0.4 \%$ (vol : vol) with ultrapure water. The $\mathrm{aCDOM}_{\text {auto }}$ at day 0 was $1.33 \mathrm{~m}^{-1}$.

For the $\mathrm{CDOM}_{\text {allo }}$ samples, $5 \mathrm{~L}$ of water was collected inside the mouth of Zala River at $1 \mathrm{~m}$ below the surface with an acid-rinsed amber glass bottle on day zero of the experiment. The predominately allochthonous origin of the DOM was confirmed by mass spectrometry (Lajtha and Michener, 1994). $0.5 \mathrm{~L}$ of water was filtered in triplicate and the filter was dried and stored until analysis on an isotope ratio mass spectrometer (ANCA-MS, Europa Scientific Ltd., UK). The ${ }^{13} \mathrm{C}$ values of the analysed allochthonous samples had a mean $\delta^{13} \mathrm{C}$ signal of $-33.48 \pm 0.43$, which is consistent with published data on the $\delta^{13} \mathrm{C}$ signature of $\mathrm{C} 3$ plants.

The $\mathrm{CDOM}_{\text {auto }}$ and $\mathrm{CDOM}_{\text {allo }}$ samples were filtered through a precombusted $47 \mathrm{~mm}$ diameter glass fibre filter paper (Fisher Brand MF300, nominal pore size $0.7 \mu \mathrm{m}$ ) previously rinsed with ultrapure water to remove particulate matter including bacteria. The samples were refiltered using $0.2 \mu \mathrm{m}$ porosity Whatman nucleopore membrane filters. The quartz tubes were acid-washed for $24 \mathrm{~h}$, and then rinsed repeatedly with ultrapure water. The tubes were then filled 
with the CDOM samples and sealed with parafilm to prevent contamination. The dark samples were wrapped with black vinyl tape (resistant to UV radiation). Data on the total solar UV-radiation during the experiment were obtained from the Hungarian Meteorological Service.

One $\mathrm{CDOM}_{\text {allo }}$ and one $\mathrm{CDOM}_{\text {auto }}$ sample were collected and analysed in triplicate at daily time steps and their absorption and fluorescence spectra were measured. CDOM absorption coefficients were measured according to the methods detailed above. Subsamples for fluorescence measurements were stored cold $\left(4^{\circ} \mathrm{C}\right)$ and in the dark after preservation with a $0.5 \%$ ( $\mathrm{vol}$ : vol) of $10 \mathrm{~g} \mathrm{~L}^{-1}$ sodium azide $\left(\mathrm{NaN}_{3}\right)$ (Ferrari et al., 1996) until further analysis.

Spectral fluorescence signatures (SFS) were measured using an Instant Screener (ISC) analyser (Laser Diagnostic Instruments Ltd., Tallinn, Estonia). Measurements were made using a $1 \mathrm{~cm}$ quartz cuvette at excitation wavelengths from 240 to $360 \mathrm{~nm}$ and at emission wavelengths from 260 to $575 \mathrm{~nm}$ with a $5 \mathrm{~nm}$ slit-widths for excitation and emission wavelengths. Ultrapure water with $0.5 \% \mathrm{NaN}_{3}$ was used as a reference. The fluorescence signals of the samples were examined in two spectral regions. "Protein-like" fluorescence $\left(F_{n}(280)\right)$ was excited at a wavelength of $280 \mathrm{~nm}$, with the emission peak recorded in the range $350 \pm 5 \mathrm{~nm}$. "Humiclike" fluorescence $\left(F_{n}(355)\right)$ was excited at $355 \mathrm{~nm}$ and its emission was measured at $450 \pm 5 \mathrm{~nm}$ (Vodacek et al., 1997; Vignudelli et al., 2004). The fluorescence data were expressed as QSU (quinine sulfate units; Coble et al., 1998).

\section{Results}

\subsection{Seasonal variability}

\subsubsection{CDOM optical properties}

There was some (pronounced in basin 1, noticeable in basin 2 and low in basin 4) seasonal variability in the CDOM concentration measured in Lake Balaton over a year (Fig. 2, Table 1). It should be stressed that seasonal changes were only measured for 1 year and may not represent the typical seasonal cycle observed over longer time periods. High $a_{\mathrm{CDOM}}(440)$ values were observed throughout the year at the mouth of the Zala River in the Keszthely basin at ST01 (Table 2), with concentrations increasing from an annual minimum in spring $\left(3.69 \mathrm{~m}^{-1}\right.$ in March) to a peak in August $\left(9.01 \mathrm{~m}^{-1}\right)$ during the warmest and driest period of the year (Anda and Varga, 2010). Values of $a_{\mathrm{CDOM}}(440)$ decreased for ST03 $\left(0.64 \mathrm{~m}^{-1}\right.$ in June $-1.43 \mathrm{~m}^{-1}$ in March) and were consistently lower and less variable in the other lake basins with a maximum value of $0.63 \mathrm{~m}^{-1}$ observed at ST12 (Szigliget) in September and a minimum value of $0.06 \mathrm{~m}^{-1}$ at ST30 (Siófok) in June.

The lowest and highest $S_{\mathrm{CDOM}}(350-500)$ coefficients were observed in Keszthely (I) basin and ranged from
Table 1. Seasonal variability of $a_{\mathrm{CDOM}}$ (440) for permanent stations.

\begin{tabular}{lrrrrrr}
\hline Month & ST01 & ST02 & ST03 & ST04 & ST05 & ST06 \\
\hline 3 & 3.694 & 1.435 & NA & NA & 0.265 & NA \\
4 & 5.485 & 1.244 & 0.617 & 0.468 & 0.228 & 0.302 \\
5 & 6.831 & 0.912 & 0.603 & 0.615 & 0.221 & 0.329 \\
6 & 6.872 & 0.637 & 0.417 & 0.152 & 0.145 & 0.062 \\
7 & 7.547 & 0.670 & 0.419 & 0.274 & 0.088 & 0.111 \\
8 & 9.005 & 0.746 & 0.507 & 0.431 & 0.258 & 0.189 \\
9 & 6.172 & 0.930 & 0.633 & 0.265 & 0.196 & 0.170 \\
MAX & 9.005 & 1.435 & 0.633 & 0.615 & 0.265 & 0.329 \\
MIN & 3.694 & 0.637 & 0.417 & 0.152 & 0.088 & 0.062 \\
MEAN & 6.515 & 0.939 & 0.533 & 0.367 & 0.200 & 0.194 \\
\hline
\end{tabular}

$0.0161 \mathrm{~nm}^{-1}$ in August at ST01 to $0.0221 \mathrm{~nm}^{-1}$ in June at ST03 (Fig. 2). $S_{\mathrm{CDOM}}$ was more variable with increasing distance from the inflow; all the stations except for ST01 demonstrated a maximum in early or mid-summer (JuneJuly) and minima in spring and autumn (Table 2). The maximum value for $S_{\mathrm{CDOM}}(350-500)$ was $0.0300 \mathrm{~nm}^{-1}$ at ST30 in June and the minimum observed was $0.0158 \mathrm{~nm}^{-1}$ at ST30 in May, highlighting the high variability of this parameter near the outflow. The mean (and range) in $S_{\mathrm{CDOM}}(350-500)$ for Lake Balaton in the summer period was $0.0211 \mathrm{~nm}^{-1}$ $\left(0.0174\right.$ to $\left.0.0229 \mathrm{~nm}^{-1}\right)$, higher than values reported in several other spatial variation studies including Lake Erie (Binding et al., 2008; $S_{\mathrm{CDOM}}(350-400) 0.0161 \mathrm{~nm}^{-1}$ ) and Lake Chapman (O'Donnell et al., 2013; $S_{\mathrm{CDOM}}(400-500)=$ $\left.0.0179 \mathrm{~nm}^{-1}\right)$.

$S_{\mathrm{CDOM}}(350-500)$ values for Keszthely and Siófok basins were negatively correlated with $a_{\mathrm{CDOM}}(440)$ (Fig. 3a and b) $\left(R^{2}=0.78, p<0.001\right.$ for the Keszthely basin and $R^{2}=0.92$, $p<0.001$ for the Siófok basin). The relationship between $S_{\mathrm{CDOM}}$ and $a_{\mathrm{CDOM}}$ in the Szigliget and Szemes basins was also negative $\left(R^{2}=0.91, p=0.01\right.$ for Szigliget and $R^{2}=$ $0.79, p=0.01$ for Szemes) (Fig. 3b).

\subsubsection{DOC}

Seasonal variation in DOC was measured at six permanent sampling stations (stations 01 and 03 from Basin Keszthely (I), station 12 from Basin Szigliget (II), station 20 from Basin Szemes (III), stations 25 and 30 from Basin Siófok (IV). DOC concentrations ranged from 7.63 at ST25 in April to $19.70 \mathrm{mg} \mathrm{L}^{-1}$ at ST01 in July with a mean value of $10.1 \mathrm{mg} \mathrm{L}^{-1}$ (Table 2). The highest concentrations were observed at ST01 (where the Zala River enters the lake) in summer (July: mean $19.7 \mathrm{mg} \mathrm{L}^{-1}$, August: mean $18.6 \mathrm{mg} \mathrm{L}^{-1}$ ) with a slightly smaller secondary peak in early autumn (October: mean $18.9 \mathrm{mg} \mathrm{L}^{-1}$ ) (Fig. 2). However, a slightly different trend was observed in the central part of Keszthely basin at ST03, where DOC started increasing at the end of the summer, reaching a maximum in November $\left(12.7 \mathrm{mg} \mathrm{L}^{-1}\right)$. For 


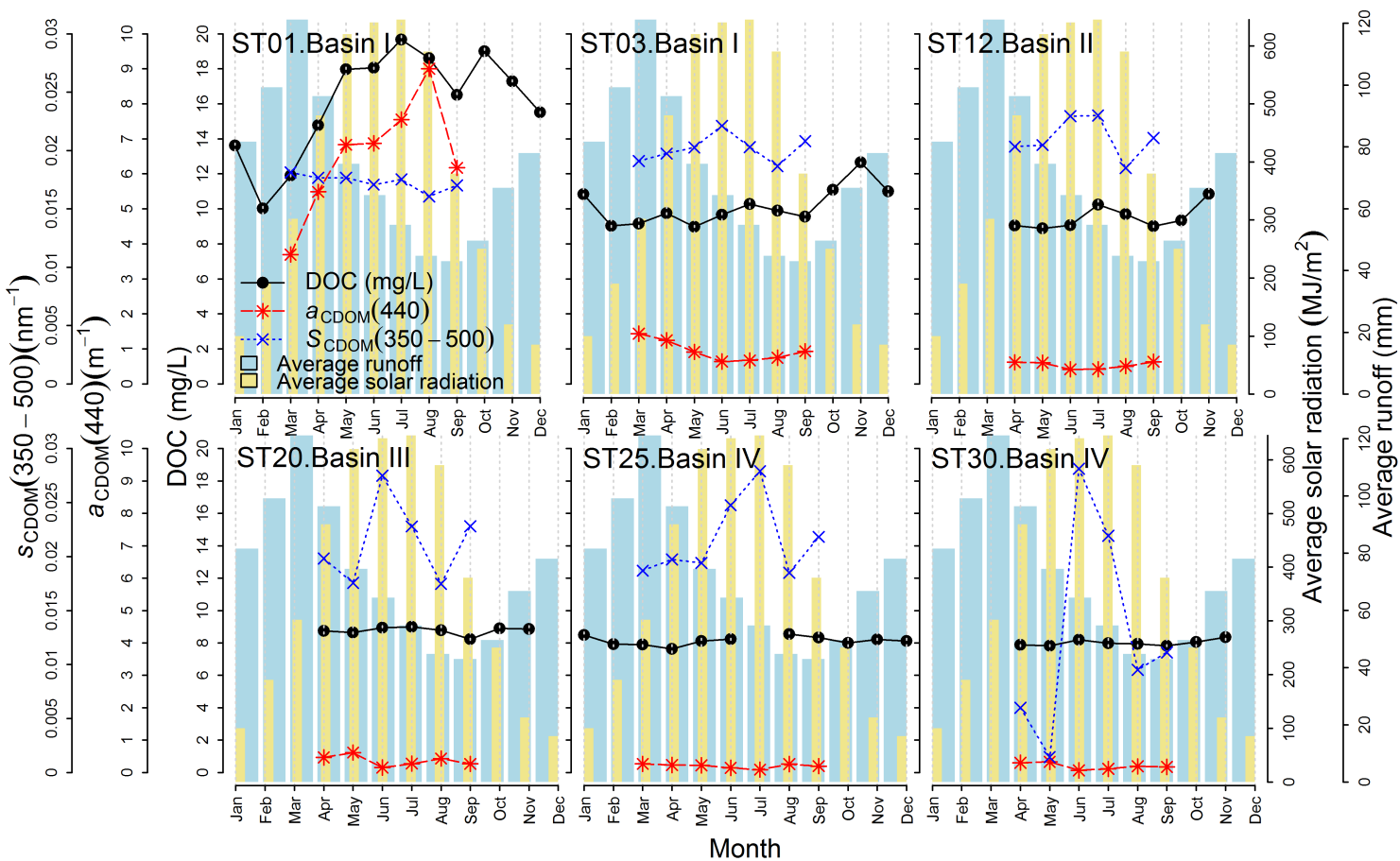

Figure 2. Seasonal $a_{\mathrm{CDOM}}(440), \operatorname{SCDOM}(350-500)$ and DOC concentration variation in Lake Balaton between January and December 2014 and seasonal variability of run-off in Balaton region (Hungary), monthly means from 1921 to 2007 (modified from Anda and Varga, 2010).
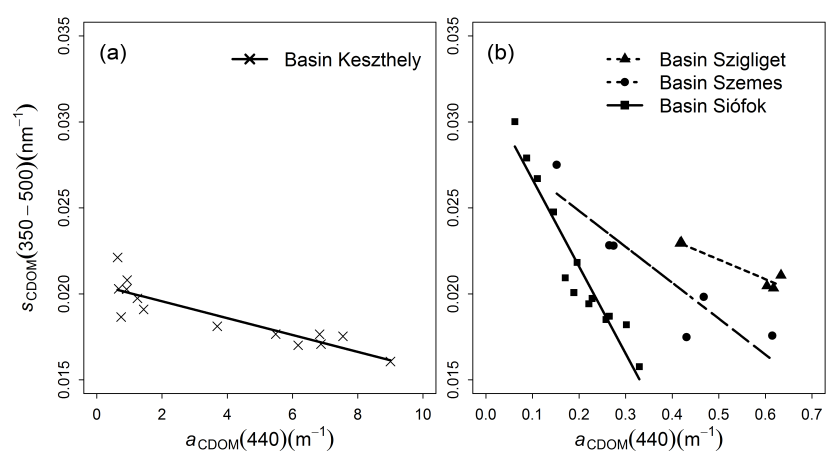

Figure 3. Plot of $S_{\mathrm{CDOM}}(350-500)$ as a function of $a_{\mathrm{CDOM}}(440)$ using the seasonal sampling data for (a) basin Keszthely, $S_{\mathrm{CDOM}}(350-500)=-0.0005 \cdot a_{\mathrm{CDOM}}(440)+0.0205, R^{2}=$ $0.7833, p<0.001$ and (b) basin Szigliget, $S_{\mathrm{CDOM}}(350-500)=$ $-0.0114 \cdot a_{\mathrm{CDOM}}(440)+0.0277, R^{2}=0.9122, p=0.011$; basin Szemes, $S_{\mathrm{CDOM}}(350-500)=-0.0209 \cdot a_{\mathrm{CDOM}}(440)+0.0209$, $R^{2}=0.7932, p=0.0108$ and basin Siófok, $S_{\mathrm{CDOM}}(350-500)=$ $-0.0507 \cdot a_{\mathrm{CDOM}}(440)+0.0317, R^{2}=0.9154, p<0.001$.

stations furthest from the main inflow, DOC concentrations remained relatively consistent during the course of the year, with two small peaks at ST12 in July and November. DOC concentrations at ST20, 25 and 30 were significantly lower at the $p<0.5$ level than ST01, 03 (ANOVA $(F(1,57)=31.63$, $p<0.001)$.

\subsection{Spatial variability}

\subsubsection{CDOM optical properties}

We observed an $a_{\text {CDOM }}$ gradient across the lake (Fig. 5a) with higher $a_{\mathrm{CDOM}}(440)$ values in Kis-Balaton and the Keszthely basin (I) (where the Zala River enters into the lake) decreasing rapidly towards the north-eastern basins near the outflow. The $a_{\mathrm{CDOM}}(440)$ coefficients were markedly different across basins ranging from 0.17 to $7.89 \mathrm{~m}^{-1}$ with the highest value observed in the Keszthely basin at the mouth of the Zala River (Fig. 5a and Fig. 6a) (Table 3).

$S_{\text {CDOM }}$ coefficients showed marked variability (0.0174$0.0229 \mathrm{~nm}^{-1}$ ) compared to previous studies in inland and marine waters (e.g. Helms et al., 2008). There was no consistent trend in $S_{\mathrm{CDOM}}$ coefficients across the lake, although the lowest values generally occurred in the western basin near the inflow (Fig. 5b, Fig. 6b). In the Kestzthely (I) basin and the western parts of Szigliget (II) basin nearest the inflow of the Zala River, higher variability was observed more with lower $S_{\mathrm{CDOM}}$ coefficients than elsewhere in the lake. In our study, $S_{\mathrm{CDOM}}(350-500)$ exhibited a negative correlation with $a_{\mathrm{CDOM}}(440)$ (Fig. 7a and b) as has been shown in previous studies (e.g. Stedmon et al., 2000; Del Castillo and Coble, 2000; Yacobi et al., 2003; Rochelle-Newall et al., 2004; Zhang et al., 2007a; Kowalczuk et al., 2003).

The $E 2: E 3$ ratio varied significantly $\left(R^{2}=0.47\right.$, $p<0.001)$ between the mouth of the river (11.1) and the 
Table 2. Values of CDOM absorption coefficient at $440 \mathrm{~nm}, \mathrm{CDOM}$ slope coefficient between 350 and $500 \mathrm{~nm}$, DOC concentration, E2 : E3 ratio, SUVA254 and mean distance of the basin to Zala River. Values obtained for CDOM seasonal variation.

\begin{tabular}{|c|c|c|c|c|c|}
\hline Station & Basin & $\begin{array}{l}a_{\mathrm{CDOM}}(440) \\
\left(\mathrm{m}^{-1}\right) \\
\text { Min-max } \\
\text { Season } \\
(\text { Mean } \pm \mathrm{SD})\end{array}$ & $\begin{array}{l}S_{\mathrm{CDOM}}(350-500) \\
\left(\mathrm{nm}^{-1}\right) \\
\text { Min-max } \\
\text { Season } \\
(\text { Mean } \pm \mathrm{SD})\end{array}$ & $\begin{array}{l}{[\mathrm{DOC}] \mathrm{mg} \mathrm{L}^{-1}} \\
\text { Min-max } \\
\text { Season } \\
(\text { Mean } \pm \mathrm{SD})\end{array}$ & $\begin{array}{l}\text { Distance to } \\
\text { Zala River } \\
(\mathrm{km})\end{array}$ \\
\hline 01 & Keszthely & $\begin{array}{l}3.69-9.01 \\
\text { Summer-spring } \\
(6.52 \pm 1.54)\end{array}$ & $\begin{array}{l}0.0161-0.0181 \\
\text { Spring-summer } \\
(0.0173 \pm 0.0006)\end{array}$ & $\begin{array}{l}10.02-19.70 \\
\text { Summer-winter } \\
(16.08 \pm 2.88)\end{array}$ & 0.48 \\
\hline 03 & & $\begin{array}{l}0.64-1.43 \\
\text { Spring-summer } \\
(0.94 \pm 0.28)\end{array}$ & $\begin{array}{l}0.0187-0.0221 \\
\text { Summer-summer } \\
(0.0201 \pm 0.0011)\end{array}$ & $\begin{array}{l}8.97-12.67 \\
\text { Autumn-spring } \\
(10.15 \pm 1.04)\end{array}$ & 3.59 \\
\hline 12 & Szigliget & $\begin{array}{l}0.42-0.63 \\
\text { Autumn-summer } \\
(0.53 \pm 0.09)\end{array}$ & $\begin{array}{l}0.0185-0.0230 \\
\text { Summer-summer } \\
(0.0211 \pm 0.0016)\end{array}$ & $\begin{array}{l}8.88-10.85 \\
\text { Autumn-spring } \\
(9.51 \pm 0.66)\end{array}$ & 14.95 \\
\hline 20 & Szemes & $\begin{array}{l}0.15-0.61 \\
\text { Spring-summer } \\
(0.37 \pm 0.15)\end{array}$ & $\begin{array}{l}0.0175-0.0275 \\
\text { Summer-summer } \\
(0.0213 \pm 0.0035)\end{array}$ & $\begin{array}{l}8.23-9.00 \\
\text { Summer-autumn } \\
(8.76 \pm 0.23)\end{array}$ & 39.73 \\
\hline 25 & Siófok & $\begin{array}{l}0.09-0.26 \\
\text { Spring-summer } \\
(0.20 \pm 0.06)\end{array}$ & $\begin{array}{l}0.0185-0.0279 \\
\text { Summer-summer } \\
(0.0215 \pm 0.0033)\end{array}$ & $\begin{array}{l}7.63-8.54 \\
\text { Summer-spring } \\
(8.13 \pm 0.25)\end{array}$ & 62.86 \\
\hline 30 & & $\begin{array}{l}0.06-0.33 \\
\text { Spring-summer } \\
(0.19 \pm 0.10)\end{array}$ & $\begin{array}{l}0.0158-0.0300 \\
\text { Summer-spring } \\
(0.0219 \pm 0.0049)\end{array}$ & $\begin{array}{l}7.82-8.36 \\
\text { Autumn-spring } \\
(8.01 \pm 0.18)\end{array}$ & 69.16 \\
\hline
\end{tabular}

Table 3. Values of CDOM absorption coefficient at $440 \mathrm{~nm}$, CDOM slope coefficient between 350 and $500 \mathrm{~nm}$, DOC concentration, E2 : E3 ratio, SUVA254 and mean distance of the basin to Zala River. Values obtained for CDOM spatial variation (values July 2014).

\begin{tabular}{|c|c|c|c|c|c|c|}
\hline Basin & $\begin{array}{l}a_{\mathrm{CDOM}}(440) \\
\left(\mathrm{m}^{-1}\right) \\
\text { Min-max } \\
\text { (Mean) }\end{array}$ & $\begin{array}{l}S_{\mathrm{CDOM}}(350- \\
500)\left(\mathrm{nm}^{-1}\right) \\
\text { Min-max } \\
\text { (Mean) }\end{array}$ & $\begin{array}{l}{[\mathrm{DOC}] \mathrm{mg} \mathrm{L}^{-1}} \\
\text { Min-max } \\
\text { (Mean) }\end{array}$ & $\begin{array}{l}E 2: E 3 \text { ratio } \\
\text { Min-max } \\
\text { (Mean) }\end{array}$ & $\begin{array}{l}\mathrm{SUVA}_{254} \\
\left(\mathrm{~L} \mathrm{mg}^{-1} \mathrm{~m}^{-1}\right) \\
\text { Min-max } \\
\text { (Mean) }\end{array}$ & $\begin{array}{l}\text { Mean distance } \\
\text { to Zala River } \\
(\mathrm{km})\end{array}$ \\
\hline Kis-Balaton & $\begin{array}{l}2.45-4.66 \\
(3.58)\end{array}$ & $\begin{array}{l}0.0186-0.0191 \\
(0.0189)\end{array}$ & - & & - & \\
\hline Kestzthely & $\begin{array}{l}0.57-7.89 \\
(1.49)\end{array}$ & $\begin{array}{l}0.0174-0.0212 \\
(0.0199)\end{array}$ & $\begin{array}{l}10.9-8.85 \\
(9.66)\end{array}$ & $\begin{array}{l}34.1-11.1 \\
(15.9)\end{array}$ & $\begin{array}{l}4.45-3.59 \\
(4.04)\end{array}$ & 3.84 \\
\hline Szigliget & $\begin{array}{l}0.33-4.31 \\
(1.00)\end{array}$ & $\begin{array}{l}0.0190-0.0214 \\
(0.0209)\end{array}$ & $\begin{array}{l}9.63-8.50 \\
(8.85)\end{array}$ & $\begin{array}{l}28.8-14.4 \\
(18.9)\end{array}$ & $\begin{array}{l}4.35-3.24 \\
(3.70)\end{array}$ & 17.4 \\
\hline Szemes & $\begin{array}{l}0.26-0.34 \\
(0.294)\end{array}$ & $\begin{array}{l}0.0211-0.0221 \\
(0.0215)\end{array}$ & $\begin{array}{l}9.07-8.03 \\
(8.56)\end{array}$ & $\begin{array}{l}44.3-18.4 \\
(27.2)\end{array}$ & $\begin{array}{l}3.82-2.62 \\
(3.12)\end{array}$ & 40.0 \\
\hline Siófok & $\begin{array}{l}0.17-0.21 \\
(0.193)\end{array}$ & $\begin{array}{l}0.0203-0.0229 \\
(0.0215)\end{array}$ & $\begin{array}{l}8.99-8.14 \\
(8.66)\end{array}$ & $\begin{array}{l}62.0-24.1 \\
(42.2)\end{array}$ & $\begin{array}{l}3.13-2.47 \\
(2.69)\end{array}$ & 60.5 \\
\hline
\end{tabular}




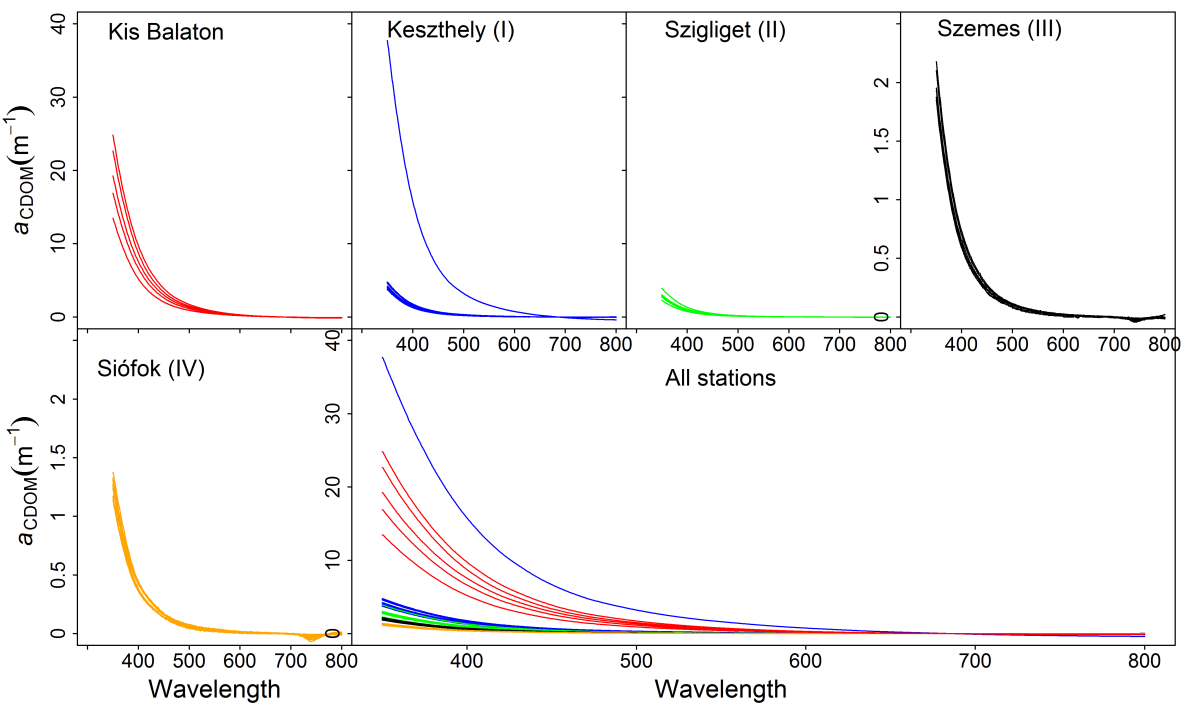

Figure 4. CDOM absorption spectra for all stations (per basin) and Kis-Balaton. Note the different $y$ axis scale for the Szemes and Siófok basins.

main outflow (62.0) as specified in Table 3. SUVA 254 varied between $2.47 \mathrm{~L} \mathrm{mg}^{-1} \mathrm{~m}^{-1}$ at ST25 in the Siófok basin to $4.45 \mathrm{~L} \mathrm{mg}^{-1} \mathrm{~m}^{-1}$ at ST06 in the Keszthely basin (Table 3). Figure $6 \mathrm{~d}$ and $6 \mathrm{e}$ shows that $\mathrm{SUVA}_{454}$ decreased with distance from the inflow of the Zala River $\left(R^{2}=0.713\right.$, $p<0.001)$, whereas the $E 2: E 3$ ratio increases with increased distance from the main inflow.

\subsubsection{DOC}

Concentrations ranged from a minimum of 8.03 at ST17 (Basin III) to $10.9 \mathrm{mg} \mathrm{L}^{-1}$ at ST07 (Basin 1) with a mean value of 9.66 in the Keszthely basin (I), 8.85 for the Szigliget basin (II), 8.56 for the Szemes basin (III) and 8.66 for the Siófok basin (IV). DOC concentrations slowly decreased with increasing distance from Zala River (Fig. 5c, Fig. 6c), similarly to the trends observed for $a_{\mathrm{CDOM}}(440)$, but with greater variability throughout the system than for $S_{\mathrm{CDOM}}$ (coefficient of variation $(\mathrm{CV})$ for $\left.S_{\mathrm{CDOM}}=0.053\right)$ and smaller than for $\mathrm{a}_{\mathrm{CDOM}}(440)\left(\mathrm{CV}\right.$ for $\left.a_{\mathrm{CDOM}}(440)=2.065\right)$. DOC concentrations showed a strong and positive relationship with $a_{\mathrm{CDOM}}(440)$ coefficients over the entire data set (Fig. 8) $\left(R^{2}=0.945, p<0.001\right)$, although for individual basins this relationship was only significant for Keszthely $\left(R^{2}=0.952\right.$, $p=<0.001)$.

\subsection{CDOM photodegradation experiment}

Ultraviolet irradiance during the photobleaching experiment ranged from 7.79 to $42.9 \mathrm{MJ} \mathrm{m}^{-2}$ per day with a mean of $32.4 \mathrm{MJ} \mathrm{m}^{-2}$ per day (Fig. 9a). The exposure of CDOM to natural solar UV radiation resulted in marked alterations to its absorption properties (Fig. 9). $a_{\mathrm{CDOM}}(440)$ remained relatively constant in the dark control samples (7.04 to $6.18 \mathrm{~m}^{-1}$ ) for the allochthonous treatment from days 0 to 7 (Fig. 9b) indicating minimal bacterial degradation of CDOM. However, the $\mathrm{CDOM}_{\text {allo }}$ samples exposed to natural solar radiation demonstrated a considerable reduction in absorption (ANOVA, $F(1,14)=12.70, p=0.003$; Fig. $9 \mathrm{~b}$ ) in the visible part of the spectrum $(440 \mathrm{~nm})$ with regard to the dark samples. After 7 days, $a_{\mathrm{CDOM}}(440)$ for the allochthonous samples decreased from 7.04 to $3.36 \mathrm{~m}^{-1}$; this equates to a rate of loss of $1.49 \mathrm{~m}^{-1} \mathrm{~d}^{-1}$ and a $42 \%$ net decrease in absorption from day 0 . The difference observed between the control samples and those exposed to natural solar radiation is indicative of a strong photobleaching effect, although it is also possible that bacterial degradation was enhanced in the light. In contrast, there was no discernible, systematic change in the $\mathrm{CDOM}_{\text {auto }}$ samples over time. They showed an increase in $a_{\mathrm{CDOM}}(440)$ during the first 3 days (Fig. 9b) from 1.22 to $1.34 \mathrm{~m}^{-1}$, but subsequently showed a decrease in absorption from 1.34 to $0.312 \mathrm{~m}^{-1}$ during the last 4 days, which equates to a $77 \%$ decrease $\left(1.03 \mathrm{~m}^{-1}\right)$ from the value at day 3 .

The autochthonous control samples $\left(\mathrm{CDOM}_{\text {auto-dark }}\right)$ varied in $a_{\mathrm{CDOM}}(440)$ from 1.22 to $0.596 \mathrm{~m}^{-1}$; in the absence of photobleaching the decrease in $a_{\mathrm{CDOM}}(440)$ might be explained by residual bacterial activity (although the samples were filtered to minimise bacterial contamination before exposure).

Photodegradation also modified the spectral slope coefficient of the samples (Fig. 9c). The values of $S_{\mathrm{CDOM}}(350$ 500) for the $\mathrm{CDOM}_{\text {allo }}$ samples remained stable, varying less than $0.001 \mathrm{~nm}^{-1}$ per day. However, for the $\mathrm{CDOM}_{\text {auto }}$ treatment, $S_{\mathrm{CDOM}}$ coefficients decreased conspicuously until the third day (from 0.009 to $0.005 \mathrm{~nm}^{-1}$ ) and then increased with further irradiation from day 3 to day 7 until recovering to 

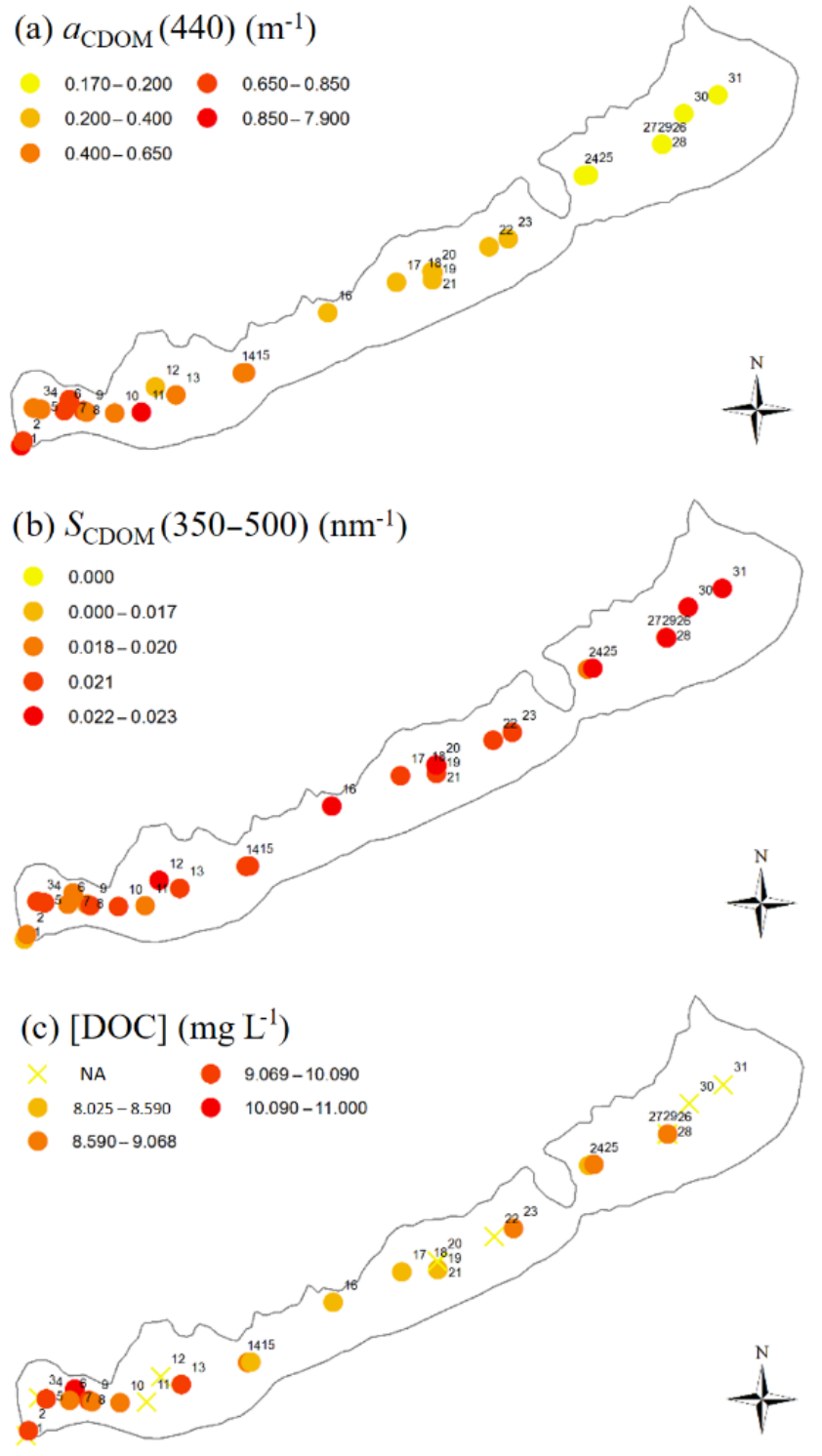

Figure 5. (a) Spatial $a_{\mathrm{CDOM}}(440)$ variation in Lake Balaton per station. (b) Spatial $S_{\mathrm{CDOM}}(350-500)$ variation in Lake Balaton per station. (c) Spatial DOC concentration in Lake Balaton per station. Data derived from measurements made in July 2014.

their original value (from 0.0051 to $0.0084 \mathrm{~nm}^{-1}$ ). Both the spectral slope (ANOVA, $F(1,14)=63.20, p<0.001$ ) and absorption coefficient (ANOVA, $\mathrm{F}(1,11)=208.65, p<0.001$ ) values for $\mathrm{CDOM}_{\text {auto }}$ were significantly lower than those for $\mathrm{CDOM}_{\text {allo. }}$.

Humic-like fluorescence as indicated by $F_{n}(355)$ decreased gradually for the $\mathrm{CDOM}_{\text {allo }}$ samples with increasing cumulative UV radiation and exposure time (Fig. 10a) from 41.1 to 17.5 QSU (42.6\% of the original value). Interestingly, no marked changes or clear trend was observed in $F_{n}(280)$ (Fig. 10b), suggesting that protein-like fluorescence was less susceptible to degradation by natural solar radiation.
There were more than 10 orders of magnitude difference in fluorescence intensity between $\mathrm{CDOM}_{\text {allo }}$ and $\mathrm{CDOM}_{\text {auto }}$ samples, presumably driven by the difference in concentration. Given the low concentrations of CDOM, after Milli-Q correction, there was no measurable fluorescence signal for the autochthonous samples.

\section{Discussion}

\subsection{Dynamics of dissolved organic carbon}

CDOM is the coloured fraction of DOC and is often the dominant light-absorbing component in lakes, particularly at blue and green wavelengths. Previous research has shown that CDOM can be responsible for up to $80 \%$ of light absorption in Lake Balaton (Riddick et al., 2015) in spite of the fact that the lake also has high concentrations of phytoplankton and non-algal particles (NAP). The high input of DOC from the Zala River results in elevated concentrations in the western basin relative to the remainder of the lake (from $0.169 \mathrm{~m}^{-1}$ near the outflow to $7.89 \mathrm{~m}^{-1}$ at the mouth of the Zala river). High DOC concentrations were largely confined to the waters nearest the inflow but the at times the influence of this input could be observed across the westernmost basin and as such must exert influence over metabolic processes in this part of the lake. In comparison to published data from other large systems such as Lake Erie (O'Donnell et al., 2010; 0.19-2.0 $\mathrm{m}^{-1}$ ), Lake Champlain (O'Donnell et al., 2013; $0.5-1.15 \mathrm{~m}^{-1}$ ) and lakes Peipsi, Vättern and Vänern (Reinart et al., 2004; 0.33-3.82 $\mathrm{m}^{-1}$ ), the magnitude of variability in $a_{\mathrm{CDOM}}(440)$ observed in this study was markedly greater (although these previous studies might not have captured the full range of $a_{\mathrm{CDOM}}(440)$ variation), which is perhaps surprising given the northerly latitude of some of these lakes (Curtis, 1998). However, the magnitude variability in $a_{\mathrm{CDOM}}(440)$ observed in this study is not too dissimilar from that reported previously in other systems such as Lake Taihu (Zhang et al., 2011; 1.37 to $9.55 \mathrm{~m}^{-1}$ ).

The seasonal pattern in CDOM absorption and DOC concentration varied considerably in the western basin, but was relatively constant in other basins. The annual peak(s) in $a_{\mathrm{CDOM}}(440)$ and DOC occurred in spring and/or autumn at some stations (e.g. ST03, ST12, ST30) and were broadly coincident with or lagged slightly behind the annual run-off maxima suggesting a seasonal trend that was partly driven by the flushing of organic matter from catchment soils during high flow events. This pattern is common in many temperate and boreal lakes where DOC export from catchments is driven by the availability of flushable terrestrial carbon sources and the seasonality of precipitation and/or snowmelt.

Conversely, at the station nearest to the inflow of the Zala River the main peak in $a_{\mathrm{CDOM}}(440)$ and DOC occurred in summer (August and July respectively) with a smaller secondary peak in DOC the autumn. The summer peak in 

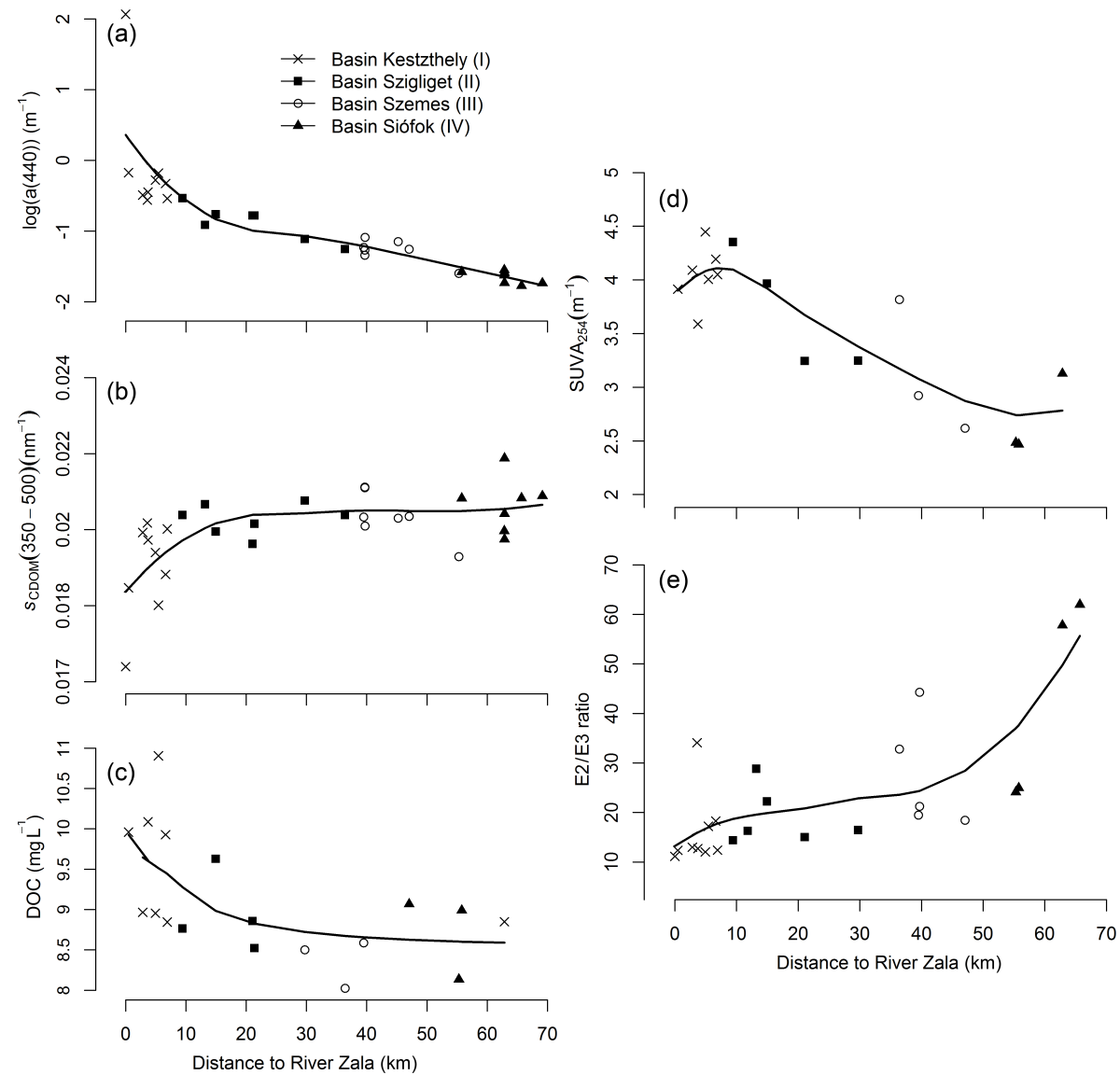

Figure 6. Scatter plots against distance to the main inflow $[\mathrm{km}]$ with loess curve fitted to data. (a) Variation of CDOM absorption coefficient at $440 \mathrm{~nm}\left(a_{\mathrm{CDOM}}(440)\right)\left[\mathrm{m}^{-1}\right]$, (b) CDOM slope coefficient between 350 and $500 \mathrm{~mm}\left(S_{\mathrm{CDOM}}(350-500)\right)$ [nm $\left.{ }^{-1}\right]$ variation, $(\mathbf{c}) \mathrm{DOC}$ concentration $\left[\mathrm{mg} \mathrm{L}^{-1}\right]$ variation, (d) specific UV absorptivity at $254 \mathrm{~nm}\left(\mathrm{SUVA}_{254}\right)\left[\mathrm{m}^{-1}\right]$ and (e) $E 2 / E 3$ ratio as a function of distance from the Zala River during the summer 2014 campaign.

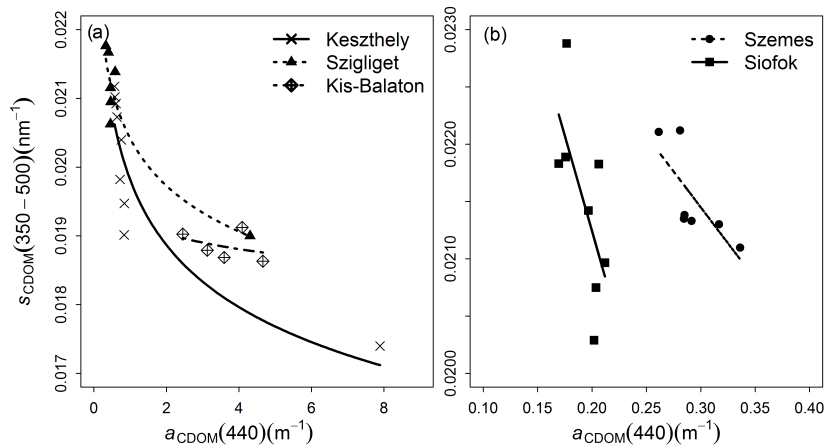

Figure 7. Plot of $S_{\mathrm{CDOM}}(350-500)$ as a function of $a_{\mathrm{CDOM}}(440)$ spatial variation. (a) Kis Balaton, $S_{\mathrm{CDOM}}(350-500)=0.019266$. $a_{\mathrm{CDOM}}(440)^{-0.017362}$; basin Keszthely, $S_{\mathrm{CDOM}}(350-500)=$ $0.019817 \cdot a_{\mathrm{CDOM}}(440)^{-0.070820}$ and basin Szigliget, $S_{\mathrm{CDOM}}(350$ $500)=0.020418 \cdot a_{\mathrm{CDOM}}(440)^{-0.070820}$. (b) Basins Szemes, $S_{\mathrm{CDOM}}(350-500)=-0.01252 \cdot a_{\mathrm{CDOM}}(440)+0.02521$ and Siofok, $S_{\mathrm{CDOM}}(350-500)=-0.03330 \cdot a_{\mathrm{CDOM}}(440)+0.027900$.
$a_{\mathrm{CDOM}}(440)$ and DOC at the inflow of the Zala River was clearly related to the proximity of the station to the mouth of the Zala River and a high input of humic-rich water from the Kis-Balaton wetland complex. In wetlands, high production of DOC can occur during the growing season due to leaching from plants and biological degradation of organic detritus (Pinney et al., 2000; Freeman et al., 2004). In our study system, this summer peak in DOC production also coincides with the annual rainfall minimum and the period of lowest flow into the lake, resulting in a concentrated input of humicrich water and elevated CDOM absorption at the inflow of the Zala and across the western basin.

It is also notable that the effect of this humic-rich water from the Zala River on the biogeochemistry and light climate in Lake Balaton diminishes rapidly through the system in summer. This can be partly attributed to the dilution of the inflow with less humic water, but also the rapid degradation of the highly biologically and photochemically reactive DOC originating from Kis-Balaton during a period when microbial activity is high due to warm water temperatures and UV irra- 


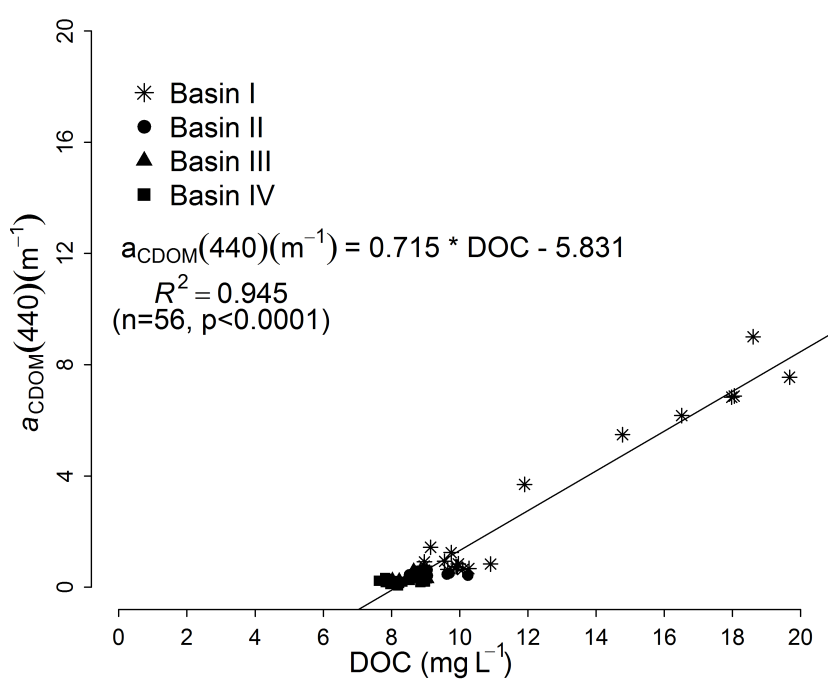

Figure 8. Scatter plot of $a_{\mathrm{CDOM}}(440)$ plotted as a function of DOC concentration $\left(\mathrm{mg} \mathrm{L}^{-1}\right)$. Line is a regression curve by least squares fit.

diance is at its maximum. The collective residence time of the Keszthely and Szigliget basins $(0.25$ and 0.72 years respectively; Somlyódy and van Straten, 2012) explains why the highly humic and labile components of the DOC entering the lake from the Zala River are largely degraded before reaching the Szemes basin with only the most recalcitrant DOC fractions persisting beyond the westernmost basins. The resulting differences in CDOM composition are clearly reflected in the variability in the CDOM absorption characteristics ( $S_{\mathrm{CDOM}}, \mathrm{SUVA}_{254}$ and $E 2: E 3$ ) observed through the system. These findings agree with other field and experimental studies which have shown that CDOM can be rapidly degraded by photobleaching in summer (Vodacek et al., 1997; Del Vecchio and Blough, 2002; Zhang et al., 2009a).

The mean (and range) in $S_{\mathrm{CDOM}}(350-500)$ for Lake Balaton in summer was $0.0211 \mathrm{~nm}^{-1}\left(0.0174\right.$ to $\left.0.0229 \mathrm{~nm}^{-1}\right)$, higher than values reported for several other systems including Lake Erie (Binding et al., 2008; $S_{\mathrm{CDOM}}(350-400)$ $0.0163 \mathrm{~nm}^{-1}$ ) and Lake Chapman (O'Donnell et al., 2013; $S_{\mathrm{CDOM}}(400-500)=0.0179 \mathrm{~nm}^{-1}$ ) (Figs. 2 and $6 \mathrm{~b}$ ). The values reported by Binding et al. (2008) and O'Donnell et al. (2013) were more comparable to the mean slopes observed for the humic-rich waters encountered in Kis-Balaton $\left(0.0189 \mathrm{~nm}^{-1}\right)$ and the Keszthely basin $\left(0.0199 \mathrm{~nm}^{-1}\right)$. However, it should be stressed that some of this variation could in part be explained by the different wavelength ranges used in the calculation of $S_{\mathrm{CDOM}}$. The magnitude of spatial variability in Lake Balaton was more comparable to that reported for northern Lake Taihu, where $S_{\mathrm{CDOM}}$ was found to vary from 0.0127 to 0.0190 , from 0.0159 to 0.0220 and from 0.0122 to $0.0174 \mathrm{~nm}^{-1}$ for the wavelength domains 280 to $500 \mathrm{~nm}, 280$ to $360 \mathrm{~nm}$ and 360 to $400 \mathrm{~nm}$ respectively
(Zhang et al., 2007a) and between 0.0180 and $0.0281 \mathrm{~nm}^{-1}$ (for $S_{\mathrm{CDOM}}(280-500)$ ) in Zhang et al. (2011).

Very few studies have investigated seasonal variation in $S_{\mathrm{CDOM}}$ in lakes. In the present study, seasonal variation in $S_{\mathrm{CDOM}}(350-500)$ was greatest in the eastern basin furthest from the inflow ranging from 0.0158 to $0.0300 \mathrm{~nm}^{-1}$ (Table 2, Fig. 2) with a mean annual value of $0.0205 \mathrm{~nm}^{-1}$. The range observed in Lake Balaton was greater than previously reported in other lake systems. Ylöstalo et al. (2014) for instance reported a mean (range) of $0.0182 \mathrm{~nm}^{-1}(0.0155-$ $0.0200 \mathrm{~nm}^{-1}$ ) for 15 boreal lakes in southern Finland in the summer months. Interestingly, there is more variation in $S_{\mathrm{CDOM}}$ in lakes and other optically complex inland waters (Kowalczuk et al., 2003; Zhang et al., 2007b) than shelf sea environments despite the fact that the latter are globally diverse and far more extensive (Babin et al., 2003).

The structural modifications in DOM and its coloured fractions that are in part conveyed through variation in $S_{\mathrm{CDOM}}$ result from interplay between the input of allochthonous DOC from the catchment, the production of autochthonous DOC from the microbial digestion of phytoplankton cells and the rate at which these materials are degraded biologically and photochemically (Zhang et al., 2009b; Yamashita and Tanoue, 2004; Vantrepotte et al., 2007; Nelson et al., 1998; Yamashita et al., 2013). Newly produced autochthonous CDOM typically has a higher $S_{\mathrm{CDOM}}$ coefficient compared to humic-rich allochthonous material (Bracchini et al., 2010). Photobleaching also results in an increase in $S_{\mathrm{CDOM}}$. The majority of sampling stations in Lake Balaton exhibited higher slope coefficients during the summer months, which could be attributed to an increase in new autochthonous DOC production from the growth and decay of phytoplankton during the summer bloom period and intense photobleaching of humicrich material received from the catchment. Seasonal variability in $S_{\mathrm{CDOM}}$ was notably lower at the inflow of the Zala River than in the easternmost basins, which again probably reflects the marked effect that intense summer photobleaching has on the structural composition of dissolved organic matter as it slow moves through the system.

Noticeably, while $a_{\mathrm{CDOM}}(440)$ and $S_{\mathrm{CDOM}}(350-500)$ demonstrated a strong inverse relationship over the entire data set, the slope of this relationship varied significantly between the different basins in the lake. The slope of the relationship is highest in the eastern basin and lower in the west near the inflow where DOC concentrations were the highest. The relationship between $a_{\mathrm{CDOM}}(440)$ and $S_{\mathrm{CDOM}}$ is known to be influenced by both its provenance and any subsequent transformations (Carder et al., 1989; Helms et al., 2008) that take place. The observed trends in Lake Balaton are likely to be a result of the mixing of water rich in allochthonous carbon from the Zala River with more dilute and autochthonous carbon sources in the main lake and the progressive degradation of this material via photobleaching as it moves through the system. Comparable trends have been found by Zhang et al. (2007b) in the Yunnan Plateau lakes. 

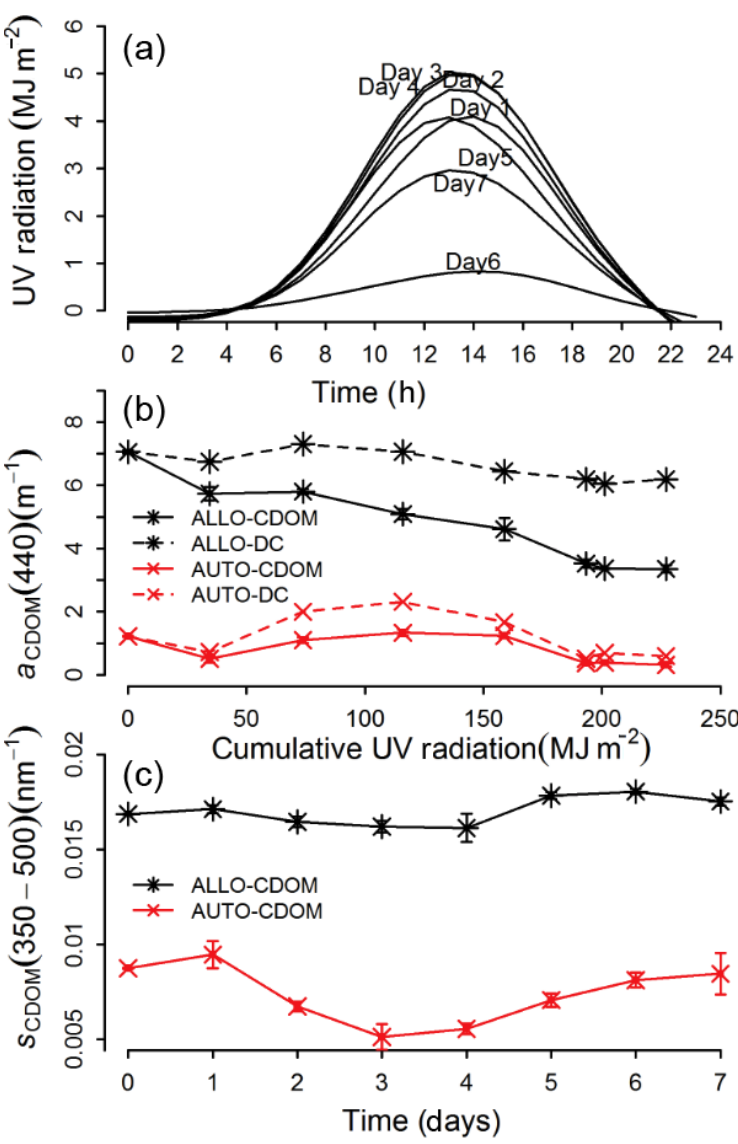

Figure 9. (a) Ultraviolet irradiance during the photobleaching experiment. (b) Variation of $S_{\mathrm{CDOM}}(350-500)$ per day. (c) Variation of $a_{\mathrm{CDOM}}(400)$ accumulated UV radiation.

$E 2: E 3$ ratio variations found in this study have also been shown in previous studies (Santos et al., 2014; Helms, 1998). In coastal waters $E 2: E 3$ values are typically within the range $8.70 \pm 1.4$ and $13.5 \pm 1.6$ (nearshore - offshore in Georgia Bight; Helms et al., 2008). In inland and transitional waters, $E 2: E 3$ ratios as high as 14.6 have been reported in Lake Taihu (Zhang et al., 2011) and up to 26.9 in Chesapeake Bay (Helms et al., 2008). E2:E3 values for Lake Balaton were significantly higher and more variable than previously reported varying between 11.0 and 72.0 , with the highest values near the outflow indicating the CDOM here was less humified and had a lower molecular weight. Increasing values of $E 2: E 3$ ratio have been reported by other authors indicating a decrease in colour as well as in molecular weight (Helms et al., 2008; Peuravuori and Pihlaja, 1997).

Similar trends were also observed in $\mathrm{SUVA}_{254}$. In Lake Balaton, SUVA 254 varied between $2.5 \mathrm{mg}^{-1} \mathrm{~m}^{-1}$ in the easternmost basin and $4.5 \mathrm{~L} \mathrm{mg}^{-1} \mathrm{~m}^{-1}$ near the mouth of the Zala River. This again indicates that water entering from the river contained high molecular weight dissolved organic carbon with a high content of aromatic substances (Weishaar et al., 2003), whereas the compounds comprising the DOC in
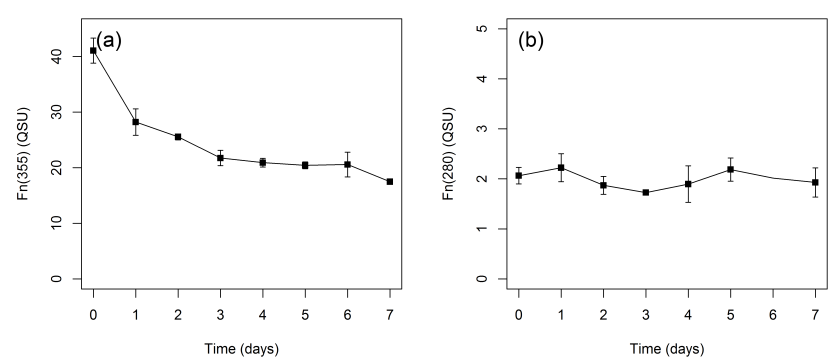

Figure 10. Changes in humic-like fluorescence $(F n$ (355)) and protein-like fluorescence $(F n(280))$ for allochthonous CDOM samples with time during photobleaching experiment. Bars show \pm standard deviation.

the central and eastern parts of the lake had a lower molecular size and aromaticity. The $\mathrm{SUVA}_{254}$ values measured in Lake Balaton were broadly comparable to those reported for other lake systems. For example, Song et al. (2013) reported a maximum value of $8.7 \pm 2.8\left(\mathrm{~L} \mathrm{mg}^{-1} \mathrm{~m}^{-1}\right)$ for 26 inland water bodies in China. SUVA 254 values were lower than those reported for marine waters where the relative contribution of autochthonous carbon sources is often greater. The sensitivity of $\mathrm{SUVA}_{254}$ to changes in the carbon provenance is shown by Asmala et al. (2013), who obtained a range of SUVA $_{254}$ values of $3.58 \pm 0.33$ and $5.41 \pm 0.40 \mathrm{~L} \mathrm{mg}^{-1} \mathrm{~m}^{-1}$ in three Baltic Sea estuaries whereas measurements taken from stations on the sea shelf varied between $1.87 \pm 0.09$ and $3.47 \pm 0.27 \mathrm{~L} \mathrm{mg}^{-1} \mathrm{~m}^{-1}$.

\subsection{CDOM photobleaching}

The spatio-seasonal variability in CDOM absorption in Lake Balaton strongly suggests that photobleaching plays a key role in the processing and degradation of dissolved organic carbon as it flows through the system. Rapid degradation of allochthonous CDOM was observed (Fig. 9), which was especially pronounced at the time of year with the highest solar radiation but probably also enhanced by mineralisation by bacterial activity as a response to high water temperatures during the summer period. Dilution processes alone cannot explain the loss of DOC; therefore, it must also be due to inlake transformation. The processing and transformation of DOC by photobleaching not only influences carbon cycling, but it also is accompanied by an increase in the transparency of the water column (Osburn et al., 2009) and changes in the optical properties (Yamashita et al., 2013) that have wider implications for the underwater light climate and primary production.

The in-lake incubations conducted in Lake Balaton provide further substantiation for the critical role of photochemistry in the turnover of CDOM. We observed rapid changes in the absorption properties of CDOM in response to exposure to natural UV irradiation. In the allochthonous CDOM treatments, the rate of degradation was higher than that ob- 
tained for Lake Taihu by Zhang et al. (2013), who reported a $22 \%$ decrease over 9 days. Bacterial degradation was not noticeable in the allochthonous samples as there was almost no difference in $a_{\mathrm{CDOM}}(440)$ for the dark treatment compared to the initial value (Fig. 9d), although we cannot exclude the possibility of enhanced bacterial degradation in lightexposed treatments (Kragh et al., 2008).

Photodegradation also modified the spectral slope (Fig. 9b) of the CDOM absorption spectra. Both the spectral slope and absorption coefficient for autochthonous CDOM were significantly lower than for allochthonous samples (ANOVA, $F(1,27)=6.55, p=0.01)$. During our experiment, $S_{\mathrm{CDOM}}(350-500)$ did not follow a systematic trend in the allochthonous samples, varying less than $0.0007 \mathrm{~m}^{-1}$ per day. However, for the autochthonous treatment, it decreased conspicuously until the third day (from 0.0087 to $0.0051 \mathrm{~m}^{-1}$ ) but then increased again from day 3 to day 7 until it almost returned to its original value (from 0.0051 to $\left.0.0084 \mathrm{~m}^{-1}\right)$. The increase in slope matches an increase in $a_{\mathrm{CDOM}}(440)$ and has been considered by Helms et al. (2008) to be a result of transformation from high to low molecular weight CDOM and is considered to be a response to photoinduced decomposition (Moran et al., 2000; Grzybowski, 2000; Yamashita et al., 2013). The initial decrease in slope during the early part of the experiment echoes observations by Yamashita et al. (2013) and Fichot and Benner (2012), who attributed this phenomena to microbial degradation of bioavailable CDOM (Nelson et al., 2004).

The fluorescence spectra also indicate a marked difference in composition between the allochthonous and autochthonous material. The decomposition of CDOM into lower molecular weight compounds under UV-B radiation (Lepane et al., 2003) results in a significant loss of both absorption and fluorescence. The negligible fluorescence signal observed for the autochthonous CDOM samples in this study is likely due to its low concentration. In contrast, the humiclike fluorescence signal measured from allochthonous samples was initially high but decreased over the experimental period from 41.07 to 17.48 QSU (57.5\% decrease). Similarly, we observed a reduction in protein-like fluorescence from 2.06 to 1.93 QSU (6.31\% decrease; Fig. 10b) over the 7 days of the experiment. This agrees strongly with the results of previous studies showing that the fluorescence signal from humic compounds is rapidly lost through photobleaching, whereas aromatic-like fluorescence is generally not as susceptible to photodegradation. Helms et al. (2013), for example, reported an $84 \%$ decrease in humic-like fluorescence in response to photobleaching compared to only a $47 \%$ decrease in aromatic-like fluorescence after 68 days of continuous irradiation in a UV solar simulator.

\subsection{Implications for the underwater light field}

The absorption of light by CDOM is a major determinant of water transparency in lakes and the availability of light for primary production (Kirk, 1994; Laurion et al., 1997, 2000; Vähätalo et al., 2005). Absence of measurements of the underwater light field makes it difficult to attribute its effect to this particular case, but there clearly exists evidence that the dynamic nature of dissolved organic carbon in lakes results in marked spatio-seasonal variation in both the magnitude and wavelength dependency of light absorption by chromophoric substances. This variability undoubtedly has implications, not only for the quantity of light available to photosynthetic organisms but also its quality. High concentrations of CDOM result in intense absorption of light at blue and green wavelengths but the intensity of absorption decreases exponentially with wavelength. This not only has implications for the productivity of the system (Cory et al., 2015), but also for the photo-physiology and species composition of the phytoplankton community. The intense absorption of UV light by CDOM protects phytoplankton from physiological damage and reduces the need for phytoplankton cells to manufacture UV-protective pigments. This can result in chromatic acclimation with phytoplankton in high CDOM waters investing less in UV-protective pigments (Riddick et al., 2015).

The magnitude of variability in the spectral dependency of CDOM absorption also has implications for bio-optical models of the underwater light field that are used to underpin remote sensing algorithms for estimation of CDOM in lakes and other inland waters. Existing bio-optical models (Lee et al., 2002) commonly extrapolate absorption by CDOM in the blue to longer wavelengths using a fixed slope coefficient. We demonstrate here that even within a single lake system significant variability can occur in $S_{\mathrm{CDOM}}$. Failure to accommodate variability in $S_{\mathrm{CDOM}}$ in bio-optical models will lead to errors, not only in the estimation of CDOM absorption but also in the contributions of other optically active substances (e.g. chlorophyll, non-algal particles) to light absorption and scattering within the water column. In Lake Balaton, the variability observed in $S_{\mathrm{CDOM}}\left(0.0174-0.0289 \mathrm{~nm}^{-1}\right)$ could produce errors up to 180 and $900 \%$ on estimates of $a_{\mathrm{CDOM}}$ at wavelengths in the blue $(350 \mathrm{~nm})$ and red $(650 \mathrm{~nm})$ respectively. This suggest that new approaches are needed to incorporate knowledge on the variability in $S_{\mathrm{CDOM}}$ into adaptive bio-optical modelling frameworks for optically complex waters to improve our ability to model the underwater light field and increase the performance of physics-based remote sensing algorithms for CDOM retrieval.

\section{Conclusions}

This study revealed the high spatial and seasonal variability in the quantity and quality of CDOM that can exist within a large, temperate shallow lake. The variation was strongly driven by the allochthonous input of dissolved carbon from the Zala River and its rapid transformation as it moves through the system. The variability in the quantity and qual- 
ity of CDOM was strongly reflected in a number of readily measured optical parameters including $S_{\mathrm{CDOM}}, E 2: E 3$ ratio and $\mathrm{SUVA}_{254}$, which collectively pointed towards a marked decrease in the molecular weight of dissolved carbon compounds, a reduction on its aromatic content and a decrease in the degree of humification as water moved through the system from the main inflow to the outflow.

Photobleaching was found to be a major factor controlling the in-lake transformation and degradation of CDOM, and a key process influencing the spatial structure CDOM throughout the system. The photobleaching rate coefficient for allochthonous CDOM was found to be higher than for autochthonous CDOM due to the greater photoreactivity of terrestrially derived compounds. CDOM in Lake Balaton is mainly terrestrial in origin and is thus rapidly degraded by exposure to UV irradiation. The implied importance of photobleaching to carbon dynamics is consistent with previous studies conducted in other inland water bodies (Zhang et al., 2013) as well as other studies carried out in shelf seas (Babin et al., 2003) and the open ocean (Helms et al., 2013).

More widely, these results provide an insight on the potential contribution of wetlands to DOM and CDOM in lakes, not only in terms of the concentration of CDOM but also its seasonality. The seasonal trend in CDOM observed close to the main inflow was significantly different from that observed elsewhere in the system. Notwithstanding the fact that most of the CDOM in Lake Balaton would seem to be terrestrial in origin, we did observe an increase in $a_{\mathrm{CDOM}}(440)$ in autumn following the breakdown of phytoplankton blooms on the lake.

The observed spatial and temporal variability in the optical properties of CDOM in this study has important implications for biogeochemical cycling in Lake Balaton but also for bio-optical models of the underwater light climate in lakes and their application in the parameterisation of algorithms for optical remote sensing of CDOM and other optically active constituents.

\section{Data availability}

The data analysed in this study are accessible through the University of Stirling DataSTORRE open access repository at http://hdl.handle.net/1893/24009 (Aulló-Maestro et al., 2016).

Author contributions. M. E. Aulló-Maestro designed and conducted the experiments with input from P. Hunter, E. Spyrakos and A. Tyler. Hajnalka Horváth and Mátyás Présing carried out data collection for seasonal measurements at Balaton Limnological Institute. Spatial measurements were taken by GloboLakes and INFORM teams. Jesús M. Torres Palenzuela contributed to fluorescence measurements at University of Vigo and Tom Preston contributed to mass spectrometry analysis at the Stable Isotope Biochemistry Laboratory at the Scottish Universities Environmental
Research Centre (SUERC). M. E. Aulló-Maestro processed the data and prepared the figures with input from Pierre Mercatoris. M. E. Aulló-Maestro prepared the manuscript with the assistance of all co-authors.

Competing interests. The authors declare that they have no conflict of interest.

Acknowledgements. The authors gratefully acknowledge funding from the UK NERC funded GloboLakes project (REF NE/J024279/1), the EU FP7 INFORM project (Grant Agreement Number 606865) and the Hungarian Academy of Science TÁMOP-4.2.2 A-11/1/KONV-2012-0038 project. Fluorescence measurements at University of Vigo were funded by a Santander doctoral travel award. Field and lab assistance on Lake Balaton was provided by Laura Ulsig, Viktória Horváth, Anett Kelemen, Eszter Zsigmond, Piroska Rádóczy, Anna Kánicz and Ádám Szigethy. Lab assistance at University of Vigo was provided by Marta Iglesias Trigo. María E. Aullo-Maestro was supported by GloboLakes project and a University of Stirling impact studentship. The authors would like to particularly emphasise their acknowledgement to the late Matyas Presing, a valued mentor and friend who greatly contributed to this research.

Edited by: B. A. Pellerin

Reviewed by: two anonymous referees

\section{References}

Adrian, R., Reilly, C. M. O., Zagarese, H., Baines, S. B., Hessen, D. O., Keller, W., Livingstone, D. M., Sommaruga, R., Straile, D., and Van Donk, E.: Lakes as sentinels of climate change, Limnol. Oceanogr., 54, 2283-2297, doi:10.4319/lo.2009.54.6_part_2.2283, 2009.

Anda, A. and Varga, B.: Analysis of precipitation on Lake Balaton catchments from 1921 to 2007, Idojaras, Q. J. Hungarian Meteorol. Serv., 114, 187-201, 2010.

Andrew, A. A., Del Vecchio, R., Subramaniam, A., and Blough, N. V.: Chromophoric dissolved organic matter (CDOM) in the Equatorial Atlantic Ocean: Optical properties and their relation to CDOM structure and source, Mar. Chem., 148, 33-43, doi:10.1016/j.marchem.2012.11.001, 2013.

Asmala, E., Autio, R., Kaartokallio, H., Pitkänen, L., Stedmon, C. A., and Thomas, D. N.: Bioavailability of riverine dissolved organic matter in three Baltic Sea estuaries and the effect of catchment land use, Biogeosciences, 10, 6969-6986, doi:10.5194/bg10-6969-2013, 2013.

Aulló-Maestro, M., Hunter, P., Spyrakos, E., Mercatoris, P., Kovács A. W., Horváth, H., Preston, T., Présing, M., Torres Palenzuela, J. M., and Tyler, A.: Spatio-seasonal variability of chromophoric dissolved organic matter absorption and responses to photobleaching in a large shallow temperate lake, University of Stirling, available at: http://hdl.handle.net/11667/76, 2016.

Babin, M., Stramski, D., Ferrari, G. M., Claustre, H., Bricaud, A., Obolensky, G., and Hoepffner, N.: Variations in the light absorption coefficients of phytoplankton, nonalgal particles, and dis- 
solved organic matter in coastal waters around Europe, J. Geophys. Res.-Ocean., 108, doi:10.1029/2001JC000882, 2003.

Benoy, G., Cash, K., McCauley, E., and Wrona, F.: Carbon dynamics in lakes of the boreal forest under a changing climate, Environ. Rev., 15, 175-189, 2007.

Binding, C., Jerome, J., Bukata, R., and Booty, W.: Spectral absorption properties of dissolved and particulate matter in Lake Erie, Remote Sens. Environ., 112, 1702-1711, doi:10.1016/j.rse.2007.08.017, 2008.

Bracchini, L., Tognazzi, A., Dattilo, A. M., Decembrini, F., Rossi, C., and Loiselle, S. A.: Sensitivity analysis of CDOM spectral slope in artificial and natural samples: an application in the central eastern Mediterranean Basin, Aquat. Sci., 72, 485-498, doi:10.1007/s00027-010-0150-y, 2010.

Bricaud, A., Morel, A., and Prieur, L.: Absorption by dissolved organic matter of the sea (yellow substance) in the UV and visible domains, Limnol. Ocean., 26, 43-53, 1981.

Buchan, A., LeCleir, G. R., Gulvik, C. A., and Gonzalez, J. M.: Master recyclers: features and functions of bacteria associated with phytoplankton blooms, Nat. Rev. Microbiol., 12, 686-698, doi:10.1038/nrmicro3326, 2014.

Carder, K. L., Steward, R. G., Harvey, G. R., and Ortner, P. B.: Marine humic and fulvic acids: Their effects on remote sensing of ocean chlorophyll, Limnol. Oceanogr., 34, 68-81, doi:10.4319/lo.1989.34.1.0068, 1989

Castillo, C. E. Del and Coble, P. G.: Seasonal variability of the colored dissolved organic matter during the 1994-95 NE and SW Monsoons in the Arabian Sea, Deep Sea Res. Pt. II, 47, 1563 1579, doi:10.1016/S0967-0645(99)00154-X, 2000.

Coble, P. G., Del Castillo, C. E., and Avril, B.: Distribution and optical properties of CDOM in the Arabian Sea during the 1995 Southwest Monsoon, Deep Sea Res. Pt. II, 45, 2195-2223, doi:10.1016/S0967-0645(98)00068-X, 1998.

Cole, J. J., Prairie, Y. T., Caraco, N. F., McDowell, W. H., Tranvik, L. J., Striegl, R. G., Duarte, C. M., Kortelainen, P., Downing, J. A., Middelburg, J. J., and Melack, J.: Plumbing the Global Carbon Cycle: Integrating Inland Waters into the Terrestrial Carbon Budget, Ecosystems, 10, 172-185, doi:10.1007/s10021-0069013-8, 2007.

Corin, N., Backhand, P., and Kulovaara, M.: Degradation products formed during UV-irradiation of humic waters, Chemosphere, 33, 245-255, doi:10.1016/0045-6535(96)00167-1, 1996.

Cory, R. M., Harrold, K. H., Neilson, B. T., and Kling, G. W.: Controls on dissolved organic matter (DOM) degradation in a headwater stream: the influence of photochemical and hydrological conditions in determining light-limitation or substratelimitation of photo-degradation, Biogeosciences, 12, 6669-6685, doi:10.5194/bg-12-6669-2015, 2015.

Curtis, P. J.: Climatic and hydrologic control of DOM concentration and quality in lakes, in Aquatic humic substances, Aquatic Humic Substances, 133, 93-105, 1998.

Cuthbert, L. D. and Del Giorgio, P.: Toward a standard method of measuring color in freshwater, Limnol. Oceanogr., 37, 13191326, 1992.

De Haan, H. and De Boer, T.: Applicability of light absorbance and fluorescence as measures of concentration and molecular size of dissolved organic carbon in humic Lake Tjeukemeer, Water Res., 21, 731-734, 1987.
Del Vecchio, R. and Blough, N. V.: Photobleaching of chromophoric dissolved organic matter in natural waters: kinetics and modeling, Mar. Chem., 78, 231-253, 2002.

D’Sa, E. J., Goes, J. I., Gomes, H., and Mouw, C.: Absorption and fluorescence properties of chromophoric dissolved organic matter of the eastern Bering Sea in the summer with special reference to the influence of a cold pool, Biogeosciences, 11, 3225-3244, doi:10.5194/bg-11-3225-2014, 2014.

Ferrari, G. M., Dowel, M. D., Grossi, S., and Targa, C.: Relationship between the optical properties of chromophoric dissolved organic matter and total concentration of dissolved organic carbon in the southern Baltic Sea region, J. Mar. Chem., 55, 299316, 1996.

Ficek, D., Zapadka, T., and Dera, J.: Remote sensing reflectance of Pomeranian lakes and the Baltic**The study was partially financed by MNiSW (Ministry of Science and Higher Education) as a research project N N306 066434 in the years 2008-2011. The partial support for this study was also pro, Oceanologia, 53, 959-970, doi:10.5697/oc.53-4.959, 2011.

Fichot, C. G. and Benner, R.: The spectral slope coefficient of chromophoric dissolved organic matter (S275-295) as a tracer of terrigenous dissolved organic carbon in riverinfluenced ocean margins, Limnol. Oceanogr., 57, 1453-1466, doi:10.4319/lo.2012.57.5.1453, 2012.

Freeman, C., Fenner, N., Ostle, N. J., Kang, H., Dowrick, D. J., Reynolds, B., Lock, M. A., Sleep, D., Hughes, S., and Hudson, J.: Export of dissolved organic carbon from peatlands under elevated carbon dioxide levels, Nature, 430, 195-198, doi:10.1038/nature02707, 2004.

Geller, A.: Comparison of mechanisms enhancing biodegradability refractory lake water constituents' Annette Geller, Limnol. Oceanol., 4, 755-764, 1986.

Grzybowski, W.: Effect of short-term sunlight irradiation on absorbance spectra of chromophoric organic matter dissolved in coastal and riverine water, Chemosphere, 40, 1313-1318, doi:10.1016/S0045-6535(99)00266-0, 2000.

Hajnal, É. and Padisák, J.: Analysis of long-term ecological status of Lake Balaton based on the ALMOBAL phytoplankton database, Hydrobiologia, 599, 227-237, doi:10.1007/s10750007-9207-x, 2008.

Hancke, K., Hovland, E. K., Volent, Z., Pettersen, R., Johnsen, G., Moline, M., and Sakshaug, E.: Optical properties of CDOM across the Polar Front in the Barents Sea: Origin, distribution and significance, J. Mar. Syst., 130, 219-227, doi:10.1016/j.jmarsys.2012.06.006, 2014.

Helms, J. R.: Spectral Shape As an Indicator of Molecular Abstract Spectral Shape As an Indicator of Molecular Weight in Chromophoric Dissolved Organic Matter, Old Dominion University, 1998.

Helms, J. R., Stubbins, A., Ritchie, J. D., Minor, E. C., Kieber, D. J., and Mopper, K.: Absorption spectral slopes and slope ratios as indicators of molecular weight, source, and photobleaching of chromophoric dissolved organic matter, Limnol. Oceanogr., 53, 955-969, doi:10.4319/lo.2008.53.3.0955, 2008.

Helms, J. R., Stubbins, A., Perdue, E. M., Green, N. W., Chen, H., and Mopper, K.: Photochemical bleaching of oceanic dissolved organic matter and its effect on absorption spectral slope and fluorescence, Mar. Chem., 155, 81-91, doi:10.1016/j.marchem.2013.05.015, 2013. 
Hoge, F. E., Vodacek, A., Swift, R. N., Yungel, J. K., and Blough, $\mathrm{N}$. V: Inherent optical properties of the ocean: retrieval of the absorption coefficient of chromophoric dissolved organic matter from airborne laser spectral fluorescence measurements, Appl. Opt., 34, 7032-7038, 1995.

IPCC, 2007: Climate Change 2007?: An Assessment of the Intergovernmental Panel on Climate Change, Intergovernmental Panel on Climate Change, ISBN 92-9169-122-4, 2007.

Istvánovics, V., Osztoics, A., and Honti, M.: Dynamics and ecological significance of daily internal load of phosphorus in shallow Lake Balaton, Hungary, Freshw. Biol., 49, 232-252, doi:10.1111/j.1365-2427.2004.01180.x, 2004.

Keiber, R. J., Zhou, X., and Mopper, K.: Formation of carbonyl compounds from UV-induced photodegradation of humic substances in natural waters: Fate of riverine carbon in the sea, Limnol. Oceanogr., 35, 1503-1515, doi:10.4319/lo.1990.35.7.1503, 1990.

Kirk, J. T. O.: Light and photosynthesis in aquatic ecosystems, Cambridge University Press, 1994, 509 pp., 1994.

Kirk, J. T. O.: Light and Photosynthesis in Aquatic Ecosystems, Third edit., Cambridge University Press, 2010.

Kowalczuk, P., Cooper, W. J., Whitehead, R. F., Durako, M. J., and Sheldon, W.: Characterization of CDOM in an organicrich river and surrounding coastal ocean in the South Atlantic Bight, Aquat. Sci., 65, 384-401, doi:10.1007/s00027-003-0678$1,2003$.

Kragh, T., Søndergaard, M., and Tranvik, L.: Exposure to sunlight and phosphorus- limitation on bacterial degradation of coloured dissolved organicmatter (CDOM) in freshwater, FEMS Microbiol. Ecol., 64, 230-239, doi:10.1111/j.15746941.2008.00449.x, 2008.

Kutser, T., Paavel, B., Metsamaa, L., and Vahtmäe, E.: Mapping coloured dissolved organic matter concentration in coastal waters, Int. J. Remote Sens., 30, 5843-5849, doi:10.1080/01431160902744837, 2009.

Lajtha, K. and Michener, R. H.: Stable Isotopes in Ecology and Environmental Science, Blackwell Scientific Publications, Oxford, 1994.

Laurion, I., Vincent, W. F., and Lean, D. R. S.: of Spectral Models for Underwater Ultraviolet Radiation?: Development Northern High Latitude Lakes, Photochem. Photobiol., 65, 107-114, 1997.

Laurion, I., Ventura, M., Catalan, J., Psenner, R., and Sommaruga, R.: Attenuation of ultraviolet radiation in mountain lakes: Factors controlling the among- and within-lake variability, Limnol. Oceanogr., 45, 1274-1288, doi:10.4319/lo.2000.45.6.1274, 2000.

Lee, Z., Carder, K. L., and Arnone, R. A.: Deriving inherent optical properties from water color: a multiband quasi-analytical algorithm for optically deep waters., Appl. Opt., 41, 5755-5772, 2002.

Lepane, V., Persson, T., and Wedborg, M.: Effects of UV-B radiation on molecular weight distribution and fluorescence from humic substances in riverine and low salinity water, Estuar. Coast. Shelf Sci., 56, 161-173, doi:10.1016/S0272-7714(02)00154-3, 2003.

Levine, S. N., Borchardt, M. A., Braner, M., and Shambaugh, A. D.: The impact of zooplankton grazing on phytoplankton species composition and biomass in Lake Champlain (USA-
Canada), J. Great Lakes Res., 25, 61-77, doi:10.1016/S03801330(99)70717-3, 1999.

Lindell, M. J., Wilhelm, G., and Tranvik, L. J.: Enhanced bacterial growth in response to photochetiical transformation of dissolved organic matter, Limnol. Oceanogr., 40, 195-199, 1995.

Matsuoka, A., Bricaud, A., Benner, R., Para, J., Sempéré, R., Prieur, L., Bélanger, S., and Babin, M.: Tracing the transport of colored dissolved organic matter in water masses of the Southern Beaufort Sea: relationship with hydrographic characteristics, Biogeosciences, 9, 925-940, doi:10.5194/bg-9-925-2012, 2012.

Matsuoka, A., Babin, M., Doxaran, D., Hooker, S. B., Mitchell, B. G., Bélanger, S., and Bricaud, A.: A synthesis of light absorption properties of the Arctic Ocean: application to semianalytical estimates of dissolved organic carbon concentrations from space, Biogeosciences, 11, 3131-3147, doi:10.5194/bg-11-3131-2014, 2014.

Millennium Ecosystem Assessment: Millennium Ecosystem Assessment, Washington, DC, World Resources Institute, 2005.

Moran, M. A., Sheldon, W. M., and Zepp, R. G.: Carbon loss and optical property changes during long-term photochemical and biological degradation of estuarine dissolved organic matter, Limnol. Oceanogr., 45, 1254-1264, doi:10.4319/lo.2000.45.6.1254, 2000.

Mózes, A., Présing, M., and Vörös, L.: Seasonal dynamics of picocyanobacteria and picoeukaryotes in a large shallow lake (Lake Balaton, Hungary), Int. Rev. Hydrobiol., 91, 38-50, doi:10.1002/iroh.200510844, 2006.

Müller, R. A., Kothawala, D. N., Podgrajsek, E., Sahlée, E., Koehler, B., Tranvik, L. J., and Weyhenmeyer, G. A.: Hourly, daily, and seasonal variability in the absorption spectra of chromophoric dissolved organic matter in a eutrophic, humic lake, J. Geophys. Res.-Biogeosci., 119.10, 1985-1998, doi:10.1002/2014JG002719, 2014.

Nelson, N. B., Siegel, D. A., and Michaels, A. F.: Seasonal dynamics of colored dissolved material in the Sargasso Sea, Deep Sea Res. Pt. I, 45, 931-957, 1998.

Nelson, N. B., Carlson, C. A., and Steinberg, D. K.: Production of chromophoric dissolved organic matter by Sargasso Sea microbes, Mar. Chem., 89, 273-287, doi:10.1016/j.marchem.2004.02.017, 2004.

O’Donnell, D. M., Effler, S. W., Strait, C. M., and Leshkevich, G. A.: Optical characterizations and pursuit of optical closure for the western basin of Lake Erie through in situ measurements, J. Great Lakes Res., 36, 736-746, doi:10.1016/j.jglr.2010.08.009, 2010.

O’Donnell, D. M., Effler, S. W., Perkins, M., and Strait, C.: Optical characterization of lake champlain: Spatial heterogeneity and closure, J. Great Lakes Res., 39, 247-258, doi:10.1016/j.jglr.2013.03.004, 2013.

Osburn, C. L., O'Sullivan, D. W., and Boyd, T. J.: Increases in the longwave photobleaching of chromophoric dissolved organic matter in coastal waters, Limnol. Oceanogr., 54, 145-159, doi:10.4319/lo.2009.54.1.0145, 2009.

Padisak, J. and Reynolds, C. S.: Selection of phytoplankton associations in Lake Balaton, Hungary, in response to eutrophication and restoration measures, with special reference to the cyanoprokaryotes, Hydrobiologia, 384, 41-53, doi:10.1023/A:1003255529403, 1998. 
Palmer, S. C. J., Pelevin, V. V., Goncharenko, I., Kovács, A. W., Zlinszky, A., Présing, M., Horváth, H., Nicolás-Perea, V., Balzter, H., and Tóth, V. R.: Ultraviolet fluorescence LiDAR (UFL) as a measurement tool for water quality parameters in turbid lake conditions, Remote Sens., 5, 4405-4422, doi:10.3390/rs5094405, 2013.

Palmer, S. C. J., Kutser, T., and Hunter, P. D.: Remote sensing of inland waters: Challenges, progress and future directions, Remote Sens. Environ., 157, 1-8, doi:10.1016/j.rse.2014.09.021, 2015.

Para, J., Charrière, B., Matsuoka, A., Miller, W. L., Rontani, J. F., and Sempéré, R.: UV/PAR radiation and DOM properties in surface coastal waters of the Canadian shelf of the Beaufort Sea during summer 2009, Biogeosciences, 10, 2761-2774, doi:10.5194/bg-10-2761-2013, 2013.

Peel, M. C., Finlayson, B. L., and McMahon, T. A.: Updated world map of the Köppen-Geiger climate classification, Meteorol. Z., 15, 259-263, doi:10.1127/0941-2948/2006/0130, 2006.

Pegau, W. S., Gray, D., and Zaneveld, J. R.: Absorption and attenuation of visible and near-infrared light in water: dependence on temperature and salinity, Appl. Opt., 36, 6035-6046, doi:10.1364/AO.36.006035, 1997.

Peuravuori, J. and Pihlaja, K.: Molecular size distribution and spectroscopic properties of aquatic humic substances, Anal. Chim. Acta, 337, 33-149, 1997.

Pinney, M. L., Westerhoff, P. K., and Baker, L.: Transformations in dissolved organic carbon through constructed wetlands, Water Res., 34, 1897-1911, doi:10.1016/S0043-1354(99)00330-9, 2000.

Présing, M., Herodek, S., Vörös, L., and Kóbor, I.: Nitrogen fixation, ammonium and nitrate uptake during a bloom of Cylindrospermopsis raciborskii in Lake Balaton, Arch. für Hydrobiol., 136, 553-562, 1996.

Présing, M., Preston, T., Takátsy, A., Sprober, P., Kovács, A. W., Vörös, L., Kenesi, G., and Kóbor, I.: Phytoplankton nitrogen demand and the significance of internal and external nitrogen sources in a large shallow lake (Lake Balaton, Hungary), Hydrobiologia, 599, 87-95, doi:10.1007/s10750-007-9191-1, 2008.

Read, J. S. and Rose, K. C.: Physical responses of small temperate lakes to variation in dissolved organic carbon concentrations, Limnol. Oceanogr., 58, 921-931, doi:10.4319/lo.2013.58.3.0921, 2013.

Reche, I., Pace, M., and Cole, J.: Interactions of Photobleaching and Inorganic Nutrients in Determining Bacterial Growth on Colored Dissolved Organic Carbon, Microb. Ecol., 36, 270-280, 1998.

Reinart, A., Paavel, B., Pierson, D., and Strömbeck, N.: Inherent and apparent optical properties of Lake Peipsi, Estonia, Boreal Environ. Res., 9, 429-445, 2004.

Riddick, C. A. L., Hunter, P. D., Tyler, A. N., Martinez-Vicente, V., Horváth, H., Kovács, A. W., Vörös, L., Preston, T., and Présing, M.: Spatial variability of absorption coefficients over a biogeochemical gradient in a large and optically complex shallow lake, J. Geophys. Res.-Ocean., 120, 7040-7066, 2015.

Rochelle-Newall, E., Delille, B., Frankignoulle, M., Gattuso, J. P., Jacquet, S., Riebesell, U., Terbruggen, A., and Zondervan, I.: Chromophoric dissolved organic matter in experimental mesocosms maintained under different $\mathrm{pCO}_{2}$ levels, Mar. Ecol. Prog. Ser., 272, 25-31, doi:10.3354/meps272025, 2004.

Santos, L., Santos, E. B. H., Dias, J. M., Cunha, A., and Almeida, A.: Photochemical and microbial alterations of DOM spectroscopic properties in the estuarine system Ria de Aveiro, Photochem. Photobiol. Sci., 13, 1146-1159, doi:10.1039/c4pp00005f, 2014.

Schindler, D. W.: Lakes as sentinels and integrators for the effects of climate change on watersheds, airsheds, and landscapes, Limnol. Oceanogr., 54, 2349-2358, doi:10.4319/lo.2009.54.6_part_2.2349, 2009.

Schwarz, J. N., Kowalczuk, P., and Chavez, F. P.: Two models for absorption by coloured dissolved organic matter, Oceanologia, 44, 209-241, 2002.

Somlyódy, L. and van Straten, G.: Modeling and managing shallow lake eutrophication: with application to Lake Balaton, Springer Science \& Business Media, 2012.

Song, K. S., Zang, S. Y., Zhao, Y., Li, L., Du, J., Zhang, N. N., Wang, X. D., Shao, T. T., Guan, Y., and Liu, L.: Spatiotemporal characterization of dissolved carbon for inland waters in semi-humid/semi-arid region, China, Hydrol. Earth Syst. Sci., 17, 4269-4281, doi:10.5194/hess-17-4269-2013, 2013.

Stedmon, C. A., Markager, S., and Kaas, H.: Optical Properties and Signatures of Chromophoric Dissolved Organic Matter (CDOM) in Danish Coastal Waters, Estuar. Coast. Shelf Sci., 51, 267-278, doi:10.1006/ecss.2000.0645, 2000.

Suttle, C. A., Chan, A. M., and Cottrell, M. T.: Infection of phytoplankton by viruses and reduction of primary productivity, Nature, 347, 467-469, doi:10.1038/347467a0, 1990.

Swan, C. M., Nelson, N. B., Siegel, D. A., and Kostadinov, T. S.: The effect of surface irradiance on the absorption spectrum of chromophoric dissolved organic matter in the global ocean, Deep Sea Res. Pt. I, 63, 52-64, doi:10.1016/j.dsr.2012.01.008, 2012.

Szilágyi, F., Somlyódy, L., and Koncsos, L.: Operation of the KisBalaton reservoir: evaluation of nutrient removal rates, Hydrobiologia, 191, 297-306, doi:10.1007/BF00026065, 1990.

Tátrai, I., Mátyás, K., Korponai, J., Paulovits, G., and Pomogyi, P.: The role of the Kis-Balaton Water Protection System in the control of water quality of Lake Balaton, Ecol. Eng., 16, 73-78, doi:10.1016/S0925-8574(00)00091-4, 2000.

Tilstone, G., Moore, G., Sorensen, K., Doerffer, R., Rottgers, R., Ruddick, K., Pasterkamp, R., and Jorgensen, P.: REVAMP regional validation of MERIS chlorophyll products in North Sea coastal waters: Protocols document, Proceedings of the "Working meeting on MERIS and AATSR Calibration and Geophysical Validation (ENVISAT MAVT-2003)", 2002.

Tranvik, L. J., Downing, J. A., Cotner, J. B., Loiselle, S. A., Striegl, R. G., Ballatore, T. J., Dillon, P., Finlay, K., Fortino, K., Knoll, L. B., Kortelainen, P. L., Kutser, T., Larsen, S., Laurion, I., Leech, D. M., Mccallister, S. L., Mcknight, D. M., Melack, J. M., Overholt, E., Porter, J. A., Prairie, Y., Renwick, W. H., Roland, F., Sherman, B. S., Schindler, D. W., Sobek, S., Tremblay, A., Vanni, M. J., Verschoor, A. M., Wachenfeldt, E. Von, and Weyhenmeyer, G. A.: Lakes and reservoirs as regulators of carbon cycling and climate, Limnol. Oceanogr., 54, 2298-2314, 2009.

Twardowski, M. S., Boss, E., Sullivan, J. M., and Donaghay, P. L.: Modeling the spectral shape of absorption by chromophoric dissolved organic matter, Mar. Chem., 89, 69-88, doi:10.1016/j.marchem.2004.02.008, 2004.

Vähätalo, A. V., Wetzel, R. G., and Paerl, H. W.: Light absorption by phytoplankton and chromophoric dissolved organic matter in the drainage basin and estuary of the Neuse River, North Car- 
olina (U.S.A.), Freshw. Biol., 50, 477-493, doi:10.1111/j.13652427.2004.01335.x, 2005.

Vantrepotte, V., Brunet, C., Mériaux, X., Lécuyer, E., Vellucci, V., and Santer, R.: Bio-optical properties of coastal waters in the Eastern English Channel, Estuar. Coast. Shelf Sci., 72, 201-212, doi:10.1016/j.ecss.2006.10.016, 2007.

Verpoorter, C., Kutser, T., Seekell, D. A., and Tranvik, L. J.: A Global Inventory of Lakes Based on High-Resolution Satellite Imagery, Geophys. Res. Lett., 41, 6396-6402, doi:10.1002/2014GL060641, 2014.

Vignudelli, S., Santinelli, C., Murru, E., Nannicini, L., and Seritti, A.: Distributions of dissolved organic carbon (DOC) and chromophoric dissolved organic matter (CDOM) in coastal waters of the northern Tyrrhenian Sea (Italy), Estuar. Coast. Shelf Sci., 60, 133-149, doi:10.1016/j.ecss.2003.11.023, 2004.

Vincent, A., Warwick, F., Laurion, I., and Pienitz, R.: Artic and Antartic lakes as optical indicators of global change, Ann. Glaciol., 27, 691-696, 1998.

Vodacek, A., Blough, N. V, Degrandpre, M. D., Peltzer, E. T., Nelson, R. K., Bloughl, N. V., and Bruce, L.: Seasonal variation of CDOM and DOC in the Middle Atlantic Bight?: Terrestrial inputs and photooxidation, Limnol. Oceanogr., 42, 674-686, 1997.

Weishaar, J. L., Aiken, G. R., Bergamaschi, B. A., Fram, M. S., Fujii, R., and Mopper, K.: Evaluation of specific ultraviolet absorbance as an indicator of the chemical composition and reactivity of dissolved organic carbon, Environ. Sci. Technol., 37, 47024708, doi:10.1021/es030360x, 2003.

Wetzel, R. G., Hatcher, P. G., and Bianchi, T. S.: Natural photolysis by ultraviolet irradiance of recalcitrant dissolved organic matter to simple substrates for rapid bacterial metabolism, Limnol. Oceanogr., 40, 1369-1380, 1995.

Wilkinson, G. M., Pace, M. L., and Cole, J. J.: Terrestrial dominance of organic matter in north temperate lakes, Global Biogeochem. Cy., 27, 43-51, doi:10.1029/2012GB004453, 2013.

Williamson, C. E., Neale, P. J., Gard, G., De Lange, H. J., and Hargreaves, B. R.: Beneficial and deterimental effects of UV on aquatic organsisms: Implications of spectral variation, Ecol. Appl., 11, 1843-1857, doi:10.2307/3061100, 2001.

Williamson, C. E., Saros, J. E., Vincent, W. F., and Smol, J. P.: Lakes and reservoirs as sentinels, integrators, and regulators of climate change, Limnol. Oceanogr., 54, 2273-2282, doi:10.4319/lo.2009.54.6_part_2.2273, 2009a.

Williamson, C. E., Saros, J. E., and Schindler, D. W.: Sentinels of Change, Science, 323, 887-888, 2009b.

Williamson, C. E., Brentrup, J. a., Zhang, J., Renwick, W. H., Hargreaves, B. R., Knoll, L. B., Overholt, E. P., and Rose, K. C.: Lakes as sensors in the landscape: Optical metrics as scalable sentinel responses to climate change, Limnol. Oceanogr., 59, 840-850, doi:10.4319/lo.2014.59.3.0840, 2014.
Wipple, G.: The microscopy of drinking water, Whipple, George Chandler, The microscopy of drinking water, Wiley, 1914.

Yacobi, Y. Z., Alberts, J. J., Takács, M., and McElvaine, M.: Absorption spectroscopy of colored dissolved organic carbon in Georgia (USA) rivers: The impact of molecular size distribution, J. Limnol., 62, 41-46, doi:10.4081/jlimnol.2003.41, 2003.

Yamashita, Y. and Tanoue, E.: In situ production of chromophoric dissolved organic matter in coastal environments, Geophys. Res. Lett., 31, 2-5, doi:10.1029/2004GL019734, 2004.

Yamashita, Y., Nosaka, Y., Suzuki, K., Ogawa, H., Takahashi, K., and Saito, H.: Photobleaching as a factor controlling spectral characteristics of chromophoric dissolved organic matter in open ocean, Biogeosciences, 10, 7207-7217, doi:10.5194/bg-107207-2013, 2013.

Ylöstalo, P., Kallio, K., and Seppälä, J.: Absorption properties of in-water constituents and their variation among various lake types in the boreal region, Remote Sens. Environ., 148, 190-205, doi:10.1016/j.rse.2014.03.023, 2014.

Zhang, Y., Qin, B., Zhu, G., Zhang, L., and Yang, L.: Chromophoric dissolved organic matter (CDOM) absorption characteristics in relation to fluorescence in Lake Taihu, China, a large shallow subtropical lake, Hydrobiologia, 581, 43-52, doi:10.1007/s10750-006-0520-6, 2007a.

Zhang, Y., Zhang, E., Liu, M., Wang, X., and Qin, B.: Variation of chromophoric dissolved organic matter and possible attenuation depth of ultraviolet radiation in Yunnan Plateau lakes, Limnology, 8, 311-319, doi:10.1007/s10201-007-0219-z, 2007b.

Zhang, Y., Zhang, E., Liu, M., Wang, X., and Qin, B.: Variation of chromophoric dissolved organic matter and possible attenuation depth of ultraviolet radiation in Yunnan Plateau lakes, Limnology, 8, 311-319, doi:10.1007/s10201-007-0219-z, 2007c.

Zhang, Y., Liu, M., Qin, B., and Feng, S.: Photochemical degradation of chromophoric-dissolved organic matter exposed to simulated UV-B and natural solar radiation, Hydrobiologia, 627, 159168, doi:10.1007/s10750-009-9722-z, 2009a.

Zhang, Y., van Dijk, M. A., Liu, M., Zhu, G., and Qin, B.: The contribution of phytoplankton degradation to chromophoric dissolved organic matter (CDOM) in eutrophic shallow lakes: field and experimental evidence, Water Res., 43(, 4685-4697, doi:10.1016/j.watres.2009.07.024, 2009 b.

Zhang, Y., Yin, Y., Liu, X., Shi, Z., Feng, L., Liu, M., Zhu, G., Gong, Z., and Qin, B.: Spatial-seasonal dynamics of chromophoric dissolved organic matter in Lake Taihu, a large eutrophic, shallow lake in China, Org. Geochem., 42, 510-519, doi:10.1016/j.orggeochem.2011.03.007, 2011. 